\title{
Building an investment
}

case.

\section{Analysing ventures for investment in the real world.}

Version 3.1

\section{Daniel Maxwell}

$17 / 02 / 2014$

A report submitted in partial fulfilment of the requirements for the degree of Master of Engineering Management. 
This page has intentionally been left blank. 


\section{Abstract}

This report presents the results of the author's summer internship with Powerhouse Ventures Ltd. It is structured in two sections.

The first describes the main theory and methodologies relevant to the practical assessment of ventures from a venture capital perspective. It goes into some detail, to demonstrate both the validity of the analysis that follows and the domain knowledge acquired by the student during the project.

The second presents an analysis of the investment opportunity presented by Fibre-gen, identifying several areas of concern. It then outlines a similar potential venture that addresses these concerns and may represent an attractive opportunity for powerHouse.

The report concludes with a series of recommendations for consideration by powerHouse, and a statement of the value gained by the student during the course of the project.

In acknowledgement of the fact that this report considers a real, privately-held venture, a number of details have been redacted in this public release. Wherever this has occurred it has been indicated in the document. 


\section{Executive summary}

This project aimed to provide the student with experience in the venture capital industry and to assess an investment opportunity presented by Fibre-gen. This report summarises the project and is comprised of two sections: the first discusses the nature of venture capital, to demonstrate the domain knowledge gained by the student, while the second presents a summary of the Fibre-gen analysis.

\section{Venture capital}

Venture capital can be described using the concept of expectation outcomes to illustrate the two activities at its core: developing an accurate understanding of the potential pay-off and inherent risk in venture opportunities. The most significant of these risks is the market risk - the risk that insufficient customers find the venture's value proposition compelling enough to pay for.

\section{Valuation}

There is no universally accepted analytical method for valuing early-stage companies. A number of different valuation approaches are discussed, but each is fundamentally limited by the assumptions forced upon them by the high uncertainty surrounding early-stage ventures.

\section{The powerHouse Way}

The Outcome Driven Innovation, Disruptive Innovation and Lean Startup methodologies constitute "The powerHouse Way". These are intended to systematically reduce market risk and are at the heart of the work performed in this project.

Outcome Driven Innovation is built upon the following steps:

1. Identifying what job consumers are looking to achieve in a given situation.

2. Defining consumers' needs as the outcomes that determine the successful execution of that job - these are the metrics by which consumers measure a product's performance and hence determine its value.

3. Uncovering market opportunities by discovering where consumers are struggling to get a job done, or one where they are under- or over-served on key performance metrics.

4. Using this information to construct a product that better addresses these key metrics, helping consumers get their job done significantly better.

Disruptive Innovation describes a process by which a product or service takes root in simple applications at the low-end of a market, then rapidly develops, moves up-market and eventually displaces established competitors. In this type of process smaller companies are typically better able to compete with incumbents than in the typical process of sustaining innovation.

The Lean Startup methodology defines the business plan of a new venture as a set of hypotheses. It then seeks to validate these through directly engaging with potential customers and developing the venture in stages through iterative, minimally-invested experiments. 
Overall, The powerHouse Way provides a method of developing ventures to minimise market risk, by continually incorporating potential consumers and their needs into ventures' development. It develops ventures in response to a perceptible market pull, promoting rapid customer uptake once product development is complete; meaning powerHousebacked ventures are more likely to succeed in the marketplace, increasing the value offered to their investors.

\section{Fibre-gen analysis}

Fibre-gen is a technology company spun out of Carter Holt Harvey during their 2005 acquisition. Fibre-gen provides acoustic instruments which allow non-destructive measurement of a number of timber parameters, most significantly stiffness, throughout the timber supply-chain. Fibre-gen has expressed board-level interest in taking on investment to support their growth.

The use of Fibre-gen's tools allows industry members to more effectively manage the variation inherent in the wood resource. This variation impacts high-end structural wood processors most significantly, typically causing $10 \%$ of their products to fail during final quality testing. Fibre-gen addresses this by allowing timber processors to identify and remove the poorest $10 \%$ of logs from their supply - the logs that cause $90 \%$ of processing problems. To do so, it relies on growers using Fibre-gen's tools early in the supply-chain, so that this information is available to processors purchasing timber down-stream. Fibre-gen motivates growers to do this by providing the opportunity to earn a premium for demonstrably stiff logs, and to identify those high-value logs that would otherwise be assumed to be of low-value.

Fibre-gen is currently in the final stages of developing an application of their technology for timber processor-heads. This product is of the most significance for Fibre-gen, primarily as a result of its position at the beginning of the harvest-processor supply-chain and its potential to access a larger NZ\$400m global annual market through a service-based business model.

A number of concerns were raised with the investment opportunity presented by Fibre-gen in its current form, specifically:

- A modest global market size;

- Market validation finding that their value proposition to timber processors was not compelling - few were willing to pay;

- Market trends towards the erosion of price premiums for quality logs, meaning growers have little motivation to demonstrate the stiffness of their logs; and

- No fundamental change being identified that investment by powerHouse could be expected to make to prompt the significant growth required for Fibre-gen to provide a desirable return. 


\section{WoodCo}

It was determined that combining Fibre-gen's technologies with tracking technology and other sensors in a new venture, "WoodCo", would overcome the majority of the issues identified with the original venture.

WoodCo would aim to provide the defining measure of wood quality at all stages in the supply-chain post-harvest. It would accomplish this by measuring a range of stiffness, strength and stability attributes at the point of harvest, tracking these against each individual log through RFID, and using this information to optimise wood-flow throughout the entire supply-chain through an online management system.

This would address the same underlying problem as Fibre-gen, but provide a more compelling solution to customers. Specifically, it would allow:

- Forest owners to optimise their returns by factoring transport costs into log-making decisions;

- Harvest managers to optimise value recovery by better understanding timber quality, and to sell logs more effectively through quantification of their quality;

- Timber processors to improve control over their output by increasing the consistency and availability of their supply; and

- Timber end users to understand the origin and provenance of their products.

Initial industry interviews validated the value of this proposition to market participants.

This venture would operate under a service-based business model, whereby harvesters pay per $\mathrm{m}^{3}$ of timber managed using the system and recoup the cost by charging a premium to downstream entities. These entities are motivated to pay this premium in order to gain more control over their supply, as this decreases their processing costs while increasing their recovery of high-value products and process control.

A top-down market sizing was necessitated by time constraints, which suggested the globally addressable market to be NZ\$1.2b annually.

The main assumptions to be tested to progress WoodCo further are:

- Bottom-up market sizing identifies a significantly large market;

- Licensing of the processor-head technology is amenable to Fibre-gen;

- Appropriate RFID technology can be obtained, and cost-effectively and reliably applied;

- Timber processors earn a significant premium for higher-quality products in all international markets; and

- Timber harvesters will be willing to physically segregate logs. 


\section{Conclusions}

As a result of the work completed it was concluded that:

- Fibre-gen do not appear to constitute an attractive investment opportunity as they currently are.

- Any venture based on advanced technology must focus on appearing simple to foresters and focus messaging on the job it does for them.

- There is a commercial opportunity to help the Forestry industry better manage its supply-chain and the inherent variability of wood.

\section{Recommendations}

As a result of the project's findings it is recommended that powerHouse:

- Begin to build an investment case for WoodCo by working to validate the assumptions listed above.

- Establish a relationship with Scion, New Zealand's primary forestry research group, to source future potential ventures.

- Investigate the commercial potential of research being conducted at the University of Canterbury into the application of telematics for machine-control in the Forestry industry. 


\section{Table of Contents}

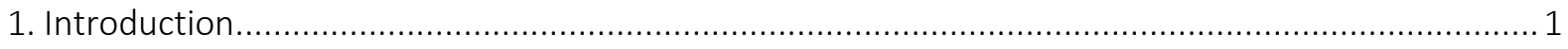

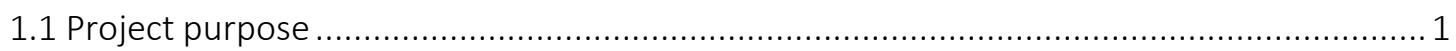

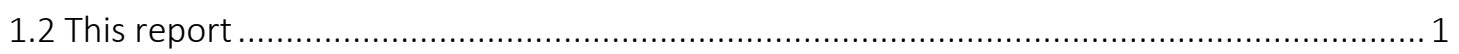

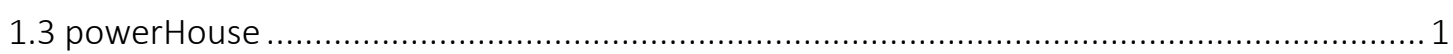

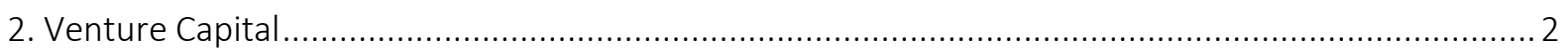

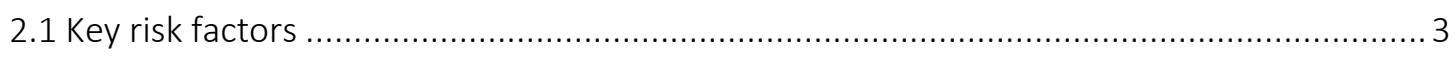

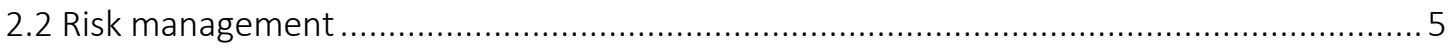

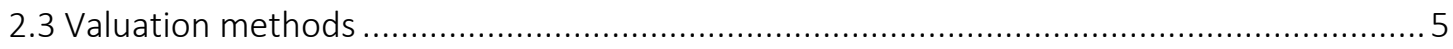

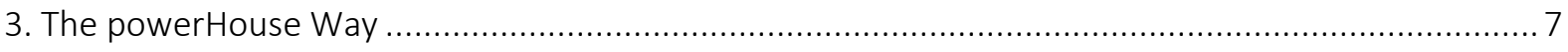

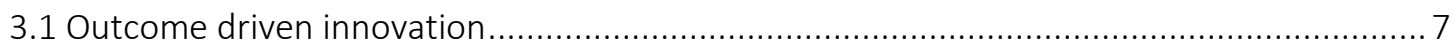

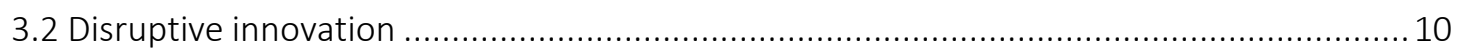

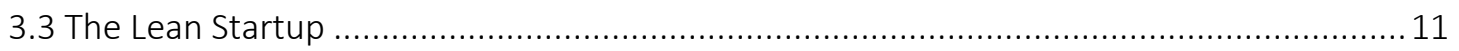

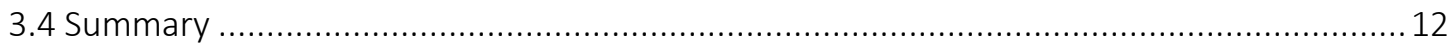

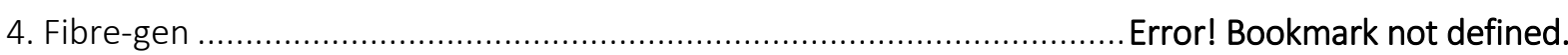

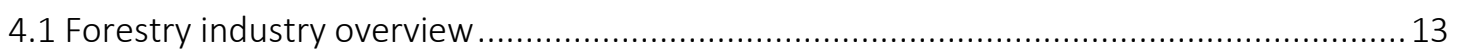

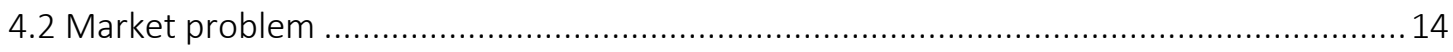

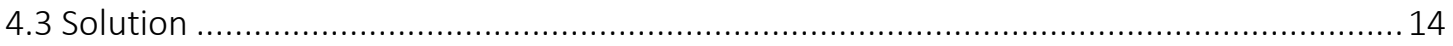

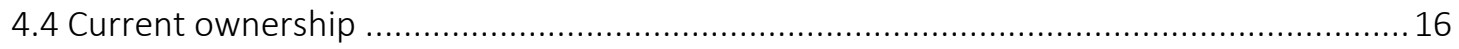

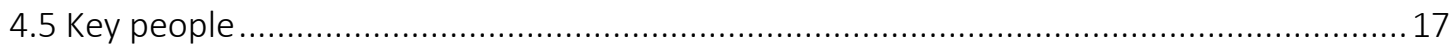

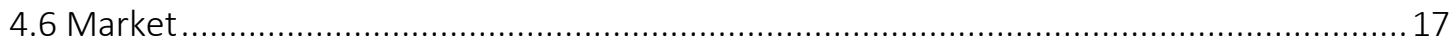

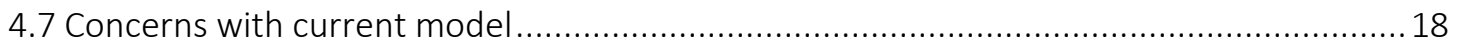

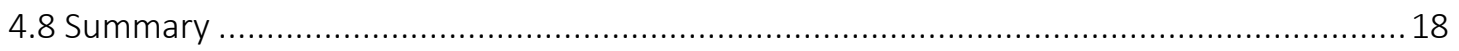

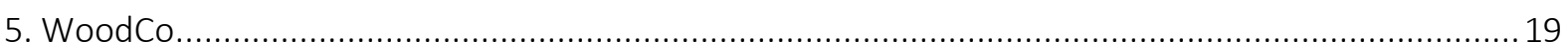

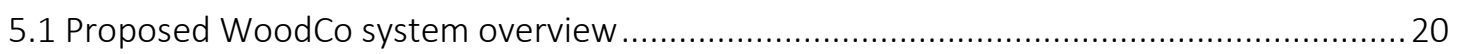

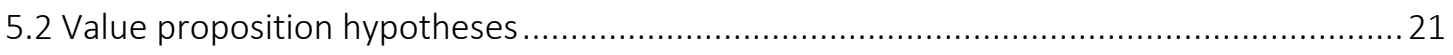

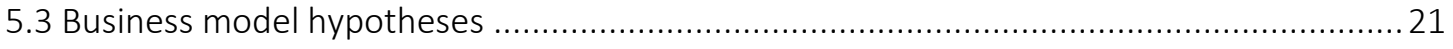

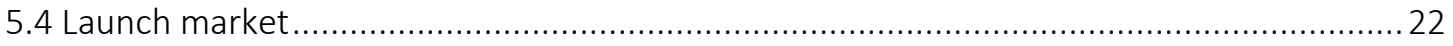

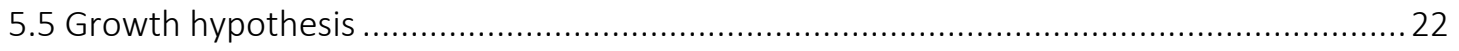

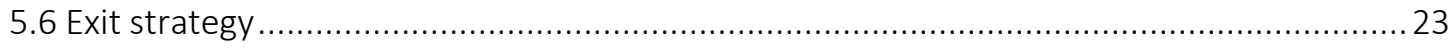

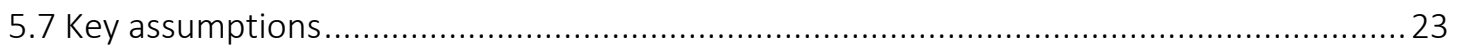

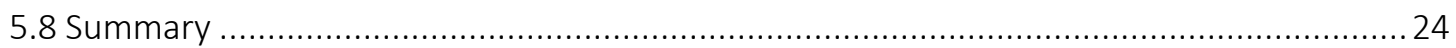

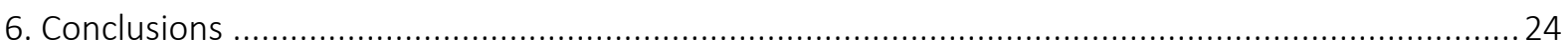

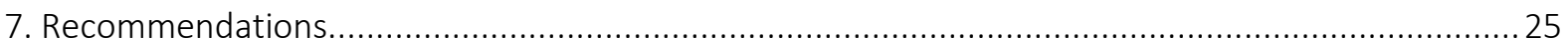




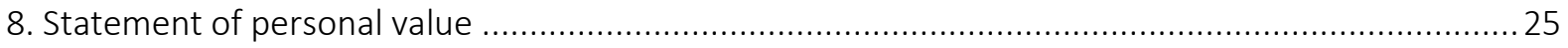

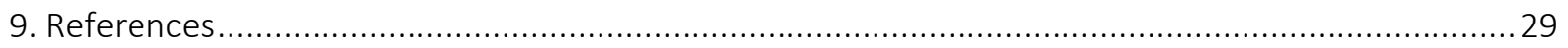

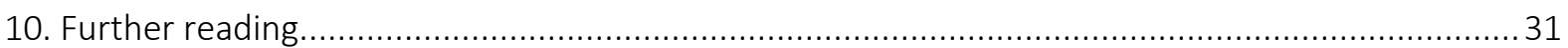

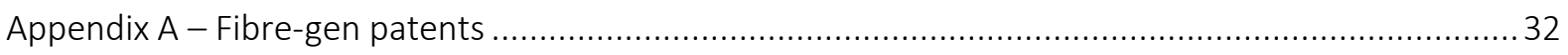

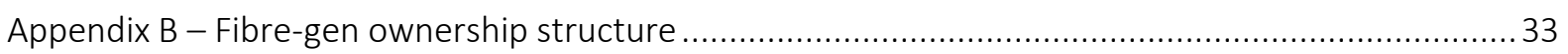

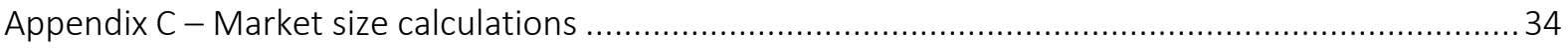

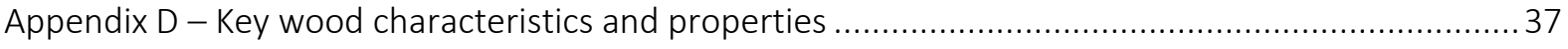

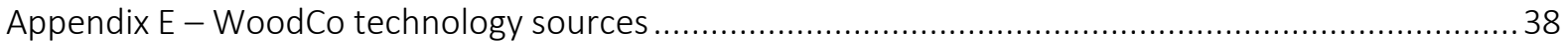

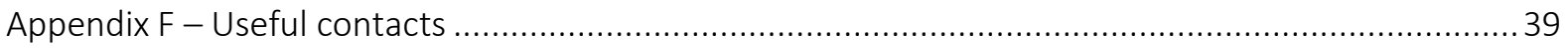

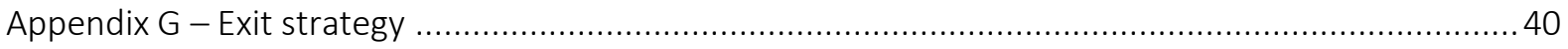

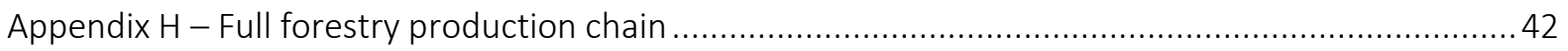

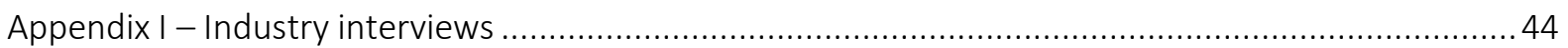




\section{Document properties}

Revision history

\begin{tabular}{|c|c|c|}
\hline Version & Date & Changes \\
\hline 1.0 & $10 / 11 / 2013$ & Drafted report wireframe. \\
\hline 1.1 & $12 / 12 / 2013$ & Begun VC review. \\
\hline 1.2 & $5 / 1 / 2014$ & Completed VC review. \\
\hline 1.3 & $6 / 1 / 2014$ & Begun Fibre-gen section. \\
\hline 1.4 & $24 / 01 / 2014$ & $\begin{array}{c}\text { Corrected formatting, } \\
\text { appendices, added front } \\
\text { matter. }\end{array}$ \\
\hline 1.5 & $28 / 01 / 2014$ & $\begin{array}{c}\text { Edits to Ulwick and Ries } \\
\text { sections. }\end{array}$ \\
\hline 1.6 & $3 / 02 / 2014$ & General edits. \\
\hline 1.7 & $4 / 02 / 2014$ & General edits. \\
\hline 1.8 & $6 / 02 / 2014$ & $\begin{array}{c}\text { Incorporated suggestions } \\
\text { from review. }\end{array}$ \\
\hline 1.9 & $7 / 02 / 2014$ & General edits. \\
\hline 2.0 & $7 / 02 / 2014$ & Final draft. \\
\hline 2.1 & $11 / 02 / 2014$ & Incorporated feedback. \\
\hline 3.0 & $17 / 02 / 2014$ & Final submission. \\
\hline 3.1 & $21 / 02 / 2014$ & $\begin{array}{c}\text { Sanitised version for library } \\
\text { upoad. }\end{array}$ \\
\hline
\end{tabular}

Distribution History

\begin{tabular}{|c|c|c|}
\hline Date & Version Number & Recipient \\
\hline $4 / 02 / 2014$ & 1.6 & $\begin{array}{c}\text { Dr Charlie Tomlinson for } \\
\text { review. }\end{array}$ \\
\hline $5 / 02 / 2014$ & 1.7 & $\begin{array}{c}\text { Dr Charlie Tomlinson for } \\
\text { review. }\end{array}$ \\
\hline $7 / 02 / 2014$ & 1.9 & $\begin{array}{c}\text { Dr Charlie Tomlinson for } \\
\text { review. }\end{array}$ \\
\hline $7 / 02 / 2014$ & 2.0 & Piet Beukman for review. \\
\hline $17 / 02 / 2014$ & 3.0 & Piet Beukman. \\
\hline $17 / 02 / 2014$ & 3.0 & Dr Charlie Tomlinson. \\
\hline $22 / 02 / 2014$ & 3.1 & $\begin{array}{c}\text { Dr Charlie Tomlinson for } \\
\text { review. }\end{array}$ \\
\hline
\end{tabular}




\section{Disclaimer}

This report has been prepared in partial fulfilment of the requirements for the degree of Master of Engineering Management at the University of Canterbury. It is intended for use by Powerhouse Ventures Ltd.

In acknowledgement of the fact this report considers a real, privately-held venture, a number of details have been redacted in this public release. Wherever this has occurred it has been indicated in the document.

While the author has taken care to make sound recommendations, they accept no responsibility for the accuracy of, nor occurrences resulting from, the use of conclusions drawn or recommendations made in this report.

A copy of this report will be submitted to the University of Canterbury on Friday 28/02/2014 in partial fulfilment of the MEM degree requirements. It will be embargoed from distribution for two years from this date. If no application is made to extend this bar, the project will be made available for unrestricted access via the University's online research repository as of 28/02/2015.

A copy will also be made available to Powerhouse Ventures Ltd on the condition that neither the student, the supervisor, nor the University of Canterbury will bear any legal responsibility for the statements made herein. If Powerhouse Ventures Ltd intends to rely on the contents of this report or to implement any of its recommendations, it must do so solely on its own judgment. 


\section{Acknowledgements}

They say it takes a village to raise an MEM, and they're definitely right in my case. As a result, I'd like to offer my sincere thanks and appreciation to the following people for all they've done for me throughout this project and the rest of my MEM:

To Dr Charlie Tomlinson - for somehow finding the time to be an awesome supervisor even with everything else that lands on your desk - I couldn't have done it without you.

To Dr Stephen Hampson, Dr Stuart Lansley, the rest of the powerHouse staff, and the CEO designates - for always having time for my questions, no matter how obscure or obtuse, and for being a great bunch of people to spend a summer with.

To the many members of the Forestry Industry who so generously helped me - for sharing your insight so freely and your patience with the lack of mine.

To Piet Beukman - for setting high standards, inspiring me to achieve them, and unflinchingly leading by example.

To Beverley Hall - for your counsel throughout the year, for chasing me when I needed to be chased, and for pulling the whole MEM show together.

To Dr Rachel Wright - for helping me in millions of ways throughout the year, especially for pointing out my (many) dumb ideas and then pointing me in the direction of better ones.

Finally, to my friends and family - for putting up with me and my erratic ramblings; I don't know how you do it, but I sure appreciate that you do. 


\section{Glossary}

Bucking. The process of cutting a stem into logs. Also known as merchandising or logmaking.

Downgrade. Lumber which is cut to structural dimensions but fails the stress grading process.

Felling. The act of cutting down a tree.

Grade recovery. The percentage of a log's volume recovered as structural grade lumber.

Knotty core size. Diameter of tree when pruned - high value clear lumber can only be recovered outside this zone.

Lumber. Timber that has been processed into battens, beams .etc.

MFA. Microfibril Angle. Refers to the angle of the microfibrils which make up the S2 layer of a wood fibre. Impacts many different macro properties. One of the most important micro properties.

MSG. Machine Stress Graded timber. Normally done by using an acoustic grading machine. Required for most structural applications.

Processor-head. A device attached to the end of a crane or tractor which grapples, fells, delimbs and bucks a tree into logs in a single operation.

Pulplog. A low value log intended for pulping.

Sawlog. A higher value log intended for structural or industrial end use.

SED. Small end diameter. The diameter of a log at its smallest end.

Stands. Sections or blocks within a forest.

Timber. Trees that have been felled but not processed - e.g. logs, stems.

Tracheid. A wood-fibre.

Volume recovery. The percentage of a log's volume recovered as lumber of any kind. 


\section{Introduction}

\subsection{Project purpose}

This project set out to analyse and shape the investment opportunity presented by Fibregen Ltd (hereafter "Fibre-gen") on behalf of Powerhouse Ventures Ltd (hereafter "powerHouse"). Specifically, the objectives were to:

1. Provide powerHouse with an analysis that could be relied upon to inform investment decisions regarding Fibre-gen;

2. Provide the student (Daniel Maxwell) with an opportunity to learn about, and gain experience in, the real-world assessment of venture opportunities; and

3. Satisfy the requirements of the student's Master of Engineering Management qualification.

\subsection{This report}

This report presents the results of the project and is structured in two sections. The first describes the main theory and methodologies relevant to the project: it goes into some detail, to demonstrate both the validity of the following analysis and the domain knowledge acquired by the student during the project. The second section presents the results of the Fibre-gen analysis.

A significant amount of supporting information is included amongst the appendices. This is done both to support brevity in the presentation of the analysis, and to provide powerHouse with a source of relevant information should they choose to proceed with investment in Fibre-gen, or any other in the Forestry Industry.

It should be noted that a vast trove of information exists on the assessment of ventures and similar topics - entrepreneurship is very much in vogue - but that much of this information is idealised and ill-informed. Consequently, care has been taken when conducting this research to only rely on information from respected publications and eschew that described by many as "business porn" (Aarons-Mele, 2014, Adams, 2002).

\section{3 powerHouse}

powerHouse is an intellectual property commercialisation company. Their core business is the creation of value for their investors through the commercialisation of intellectual property, primarily originating from Universities and Research Institutes. They focus on early-stage, high-tech companies to whom they can add the most value through their expertise and incubation services. 


\title{
2. Venture Capital'
}

\author{
"Venture capitalists are often regarded as a mystical priesthood who practice an \\ elusive, intuitive high art. However, like an assembly line, venture capitalists take \\ inputs, add value, and produce outputs. They buy businesses, add capital and \\ expertise, and then sell those businesses for a higher price." \\ - Thomas Thurston (Thurston, 2013)
}

At its core, venture capital is about expected outcomes - codified by the concept of expectation values. In the context of investment, expectation values can be reframed as

$$
E_{\text {Inv. }}=\sum \text { Risk } \times \text { Return },
$$

where if $E_{I n v .}$, the expected outcome of the investment, is larger than the opportunity cost (e.g. the result that would be expected from the next best/no investment), then the investor is expected to be better off for having taken the risk. While this by no

Definition: Expectation Value (Grinstead and Snell, 1997) Let $x$ be a numerically-valued discrete random variable with sample space $\Omega$ and distribution function $m(x)$. The expectation value is then defined by:

$$
E(x)=\sum_{x \in \Omega} x m(x),
$$

provided the sum converges absolutely. means provides a guarantee for any single investment, its application over a large set of such investments would be expected to make a good returns on the funds invested ${ }^{\mathrm{ii}}$ (Rosenman, 2013, Mauboussin, 2005, Lo, 2001, Sharpe, 2007).

\section{"Take the probability of loss times the amount of possible loss from the probability of gain times the amount of possible gain. That is what we're trying to do. It's imperfect, but that's what it's all about."$$
\text { - Warren Buffettii }
$$

The importance of expectation values is best seen through consideration of Samuelson's famous lunch bet to his colleague:

\section{"Let's flip a coin - if you call it right you win $\$ 200$, if you call it wrong you lose \$100."}

The colleague declined, but stated that he would have accepted a series of 100 such bets. The expectation value of the situation shows the bet to be heavily in the favour of the colleague:

\footnotetext{
'This report uses "venture capital" as a blanket term to cover the gamut of private-equity investments made in growing or early-stage businesses.

ii This is somewhat of a simplification, not taking into consideration variation or outright loss probabilities, but serves to illustrate the point. It also explains the recent trend towards startup "accelerators" - where large numbers of small, high-risk, high-return investments increase the likelihood that the expectation value will be achieved.

iii Attributed in MAUBOUSSIN, M. 2005. Attributes of a Good Investment Process - The Critical Role of Decision Making. In: SUNDER, S. (ed.) Yale School of Managament Lecture Series. Yale University: Legg Mason Capital Management.
} 


$$
\begin{aligned}
E_{\text {Inv. }} & =50 \% \times(-\$ 100)+50 \% \times(+\$ 200) \\
& =+\$ 50 .
\end{aligned}
$$

That is, from an actuarial point of view he should still have taken the bet ${ }^{\text {iv }}$ (Samuelson, 1963, Kahneman and Tversky, 2000, Kahneman, 2011).

While not explicitly used in this project, the expectation value concept illustrates the nature of the work carried out - developing an accurate understanding of the risks involved, identifying means of mitigating them, and developing an idea for the magnitude of potential pay-offs.

\subsection{Key risk factors}

70-90\% of new businesses and product lines fail (Christensen et al., 2005, Adams, 2010, Ulwick, 2005, Blank, 2013). While there are innumerable factors that ultimately contribute to this, the following are the most significant when assessing early stage businesses (Bell, 2000, Payne, 2007a, Adams, 2010, Loy, 2013, Roberts and Barley, 2005).

\subsubsection{Market risk}

This is the risk that there are an insufficient number of consumers willing to pay the required price for a product for it to attain the revenues required to generate an appropriate investment return.

This has three main elements: ensuring that the offering developed meets a true customer need, that the addressable market is of sufficient size - normally >US\$500 million (Adams, 2010, Roberts and Barley, 2005), and that the market size is not likely to decline over the period of the investment.

This risk is largely controllable by investors through validating market needs and value propositions, and through careful analysis of market sizes and trends.

\subsubsection{Management risk}

This is the risk that the management of a venture do

\section{Assessing risk}

The Bell-Mason diagnostic is a tool that can be used in the assessment of ventures at different stages. It plots the perceived strength of a venture opportunity against 12 key risk dimensions. It allows the implicit risk in a venture to be quickly and holistically understood, measured against predefined criteria, and for the progress of a venture to be demonstrated.

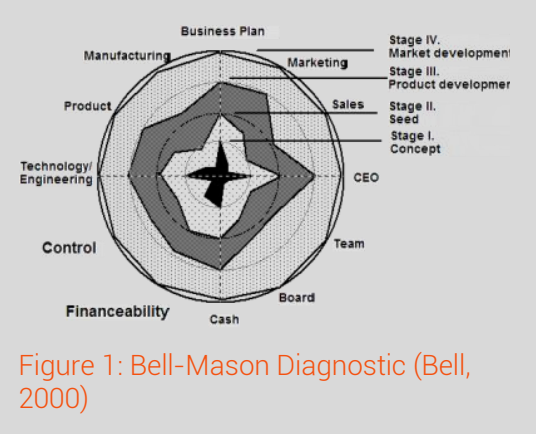
not have the skills, domain knowledge or experience necessary to successfully implement the business plan.

This is somewhat controllable by investors through analysis of the people involved, their qualifications and experience, and through investment terms which afford investors either dominant governance positions or the explicit ability to replace management should they deem it necessary.

\footnotetext{
iv Though humans rarely take an actuarial view as a result of risk aversion; a fascinating phenomenon unfortunately outside the scope of this paper.
} 


\subsubsection{Competitive risk}

This is the risk that customers will prefer competitors' existing solutions over a new product, or that competitors will be able to rapidly react to a new market entrant without significant competitive disadvantage.

Investors generally look to mitigate this by ensuring invested ventures have a significant, defensible IP advantage - primarily through patents, trade-secrets and unique capabilities or that the market in which they operate features significant financial, technological, or other barriers to entry.

\subsubsection{Technology risk}

This is the risk that the promise of a technology cannot ultimately be fulfilled - that is, that it cannot ultimately deliver the hypothesised value proposition. This could be either due to technical limitations, budget and timeframe limitations, or through the loss of key expertise with the loss of key individuals within the company.

Investors are able to mitigate this in a number of ways: many choose to operate only in domains in which they, or consultants acting on their behalf, enjoy significant expert knowledge; many invest only once a working prototype has been developed; and many work to ensure key personnel's incentives are aligned with those of the investors - usually through the grant of vested stock or stock options - and insist on "key man" life insurance policies.

\subsubsection{Exit Risk}

This is the risk that an investment will not be able to be readily liquidated; i.e. that the company is not acquired, sellable through private equity markets, and is inappropriate for IPO. It is the risk that any return will be ultimately unable to be realised.

This is primarily mitigated by investors identifying analogous companies which have successfully exited as precedents, and by identifying an exit strategy and planning for exit from the point of investment.

\subsubsection{Financial risk}

This is the risk that the capital required to successfully develop, launch and grow a venture will be unable to be attained, or that doing so will significantly dilute the investors' holding to the point that it will no longer generate a desirable return.

This can be mitigated by investors by forecasting a venture's future capital requirements, identifying the most appropriate milestones at which to attract future investment, and factoring the associated dilution into their return calculations for the initial investment. Many investors guard against this dilution through a rule of thumb whereby they only look for investments capable of potentially offering a 30x return - meaning they can still receive a good return even with significant dilution in subsequent rounds (Villalobos, 2007). 


\subsection{Risk management}

Due to the unavoidability of risk in venture capital, it is important that funds have effective risk management procedures. While a full discussion of fund risk management techniques is outside the scope of this project, the following are the key methods employed by venture capital firms:

- The primary method of risk management in investment funds is through the diversification of investments. This is generally accomplished by spreading investments across a range of unrelated sectors and development stages ${ }^{v}$. This minimizes both firm-specific risks and also risks relating to macro-variables, such as legislative changes which can rapidly impact entire industries (Dunne-Schmitt, 2004).

- Co-investment serves both to diversify risk by allowing larger numbers of smaller, diversified investments, and to reduce risk by implementing a "peer-review" of investment cases (Kut et al., 2007).

- Staged financing, contingent on the achievement of risk-reducing milestones, allows risks to be minimised before significant resources are committed (Kut et al., 2007, Loy, 2013).

\section{"Funding has the potential to turn a little failure into an enormous one."}

- Carmen Nobel (Nobel, 2011)

- Financial contracting measures, including board composition, liquidation preference, and anti-dilution clauses, are often included in term sheets. Terms such as these can be used to mitigate specific risks, and as such are an important factor when considering any deal (Kut et al., 2007, Kaplan and Strömberg, 2003).

\subsection{Valuation methods}

\section{"Many consider the valuation of a closely held business akin to alchemy." - Darryl Waldron and Carl Hubbard (Waldron and Hubbard, 1991)}

Theoretically, the valuation of a business is determined by the net present value of its future cash-flow streams, discounted for risk (Loy, 2013, Whittington, 2013) and future dilution (Sahlman, 2009). In practise, however, discounted cash-flow analyses are of little relevance to early-stage companies as both the future cash-flows and the risk discount rate are highly speculative (Loy, 2013, Ge et al., 2005). In fact, there is no universally accepted analytical methodology for assigning value to a pre-revenue start-up company (Payne, 2007a, Ge et al., 2005, Whittington, 2013).

The reality is that a number of different approaches should be employed so that a "reasonable" amount can be determined on which to base negotiations. The following are three key approaches used in industry.

\footnotetext{
${ }^{v}$ It should be noted that some funds will choose to specialise in a sector if they believe their domain knowledge affords them benefits which outweigh the inherent risk of investing in a single sector.
} 


\subsubsection{Venture-capital method}

The venture-capital is a commonly-used method which calculates the value of a venture that would satisfy investment criteria, based on an assumed exit valuation. This essentially represents what the venture is worth to a particular investor. It does so by determining and combining the price:earnings ratio ${ }^{\text {vi }}$ typical of the market category in which the venture operates, its forecast earnings at exit, and the desired ROI vii into the following simple formula viii (Payne, 2007b, Damodaran, 2009, Sahlman, 2009):

$$
\text { Post }- \text { money valuation }=\frac{\text { Price: Earnings Ratio } \times \text { Earnings at Exit }}{\text { Desired ROI Multiple }} .
$$

While useful to establish a "ball-park" figure, this method is driven more by the needs of the investor than the economic reality, and thus cannot be relied upon in isolation to determine a venture's value.

\subsubsection{Market method}

Ultimately, anything is ultimately only worth what someone is willing to pay. This is the principle at the core of the market method, which looks to identify the prices commanded by "similar" ventures - ideally of the same size, stage and industry - which are used to deduce a valuation for the venture in question (Damodaran, 2012, Ranade, 2008, Whittington, 2013).

In early-stage ventures, outright, public sales are uncommon; instead values are inferred from the investments of other firms into companies in the same sector, values which can commonly be found in media releases, financial statements, and US Securities and Exchange Commission disclosures.

This method is appealing as it is driven by thirdparty information, and hence is less likely to be

Definition: Information Asymmetry (Healy and Palepu, 2001 Dushnitsky and Shaver, 2009) Information asymmetry refers to the inherent information imbalance in the investor-entrepreneur dyad.

Typically, entrepreneurs will know much more than investors about the venture, and often the industry, in question. Conversely, investors are typically much better informed than entrepreneurs about the importance of seemingly innocuous investment terms, and of the different methods available for valuing companies.

As their incentives, particularly while closing an investment deal, can be seen to be in opposition, each party is often not motivated to be fully forthright with the other. unduly influenced by information asymmetry or the desires of the investors or venture owners (Whittington, 2013). It is limited in most cases by the capacity to find multiple ventures which are truly "similar" to early-stage, novel ventures.

\footnotetext{
vi Widely published and used throughout the finance industry.

vii Adapted for dilution if further rounds are expected. Many investors simply apply a rule of thumb $\mathrm{ROI}$ of 30x, which allows a good return even with significant dilution (also known as divergence).

viii Or a permutation thereof.
} 


\title{
2.3.3 Risk-factor summation methods
}

Risk factor-summation methods for valuing early-stage companies revolve around the observation that the most early ventures are fundamentally similar and valued within a relatively well-defined range (Payne, 2007a). Ventures are then quantitatively assessed (e.g. rated as "very safe" through to "very risky") against a number of key risk-factors, and then their position within the valuation range determined by a weighted function of their risk factor scores (Ge et al., 2005, Payne, 2007a).

Many similar "scorecard" methods can also be found that determine valuations based on scaling of an investment within a range - most notably that method of Dave Berkus which assesses the "value" of an early stage business based on 5 simple yes or no criteria. These methods are gaining in popularity due to their simplicity, their transparency and fact that more rigorous rarely attain better results in situations characterised by such a high level of uncertainty (Payne, 2013).

"Measure with a micrometer, mark with chalk, cut with an axe."

- American Proverb

\section{The powerHouse Way}

\author{
"Innovation is not an initiative; it is a business process. The process begins with \\ market selection and includes steps to uncover customer needs, determine which \\ needs are unmet, select a growth strategy and devise and evaluate product and \\ service concepts." \\ Definition of Innovation - Anthony Ulwick (Ulwick, 2009)
}

It is commonly held that the predominant reason for product failure is that the product doesn't sell; not that it cannot be built (Adams, 2002, Adams, 2010, Schneider and Hall, 2011, Ulwick, 2005). Hence, in the context of assessing early stage ventures it is the wide body of innovation literature, with its focus on market risk, which can be seen to be the most relevant. The following are those elements of this literature that constitute "The powerHouse Way", and have been referred to during this project.

\subsection{Outcome driven innovation}

\section{"This is the dirty little secret of innovation: despite all the talk about satisfying customer needs, there is very little understanding of what a customer need is - what its purpose, structure, content and syntax should be." - Anthony Ulwick (Ulwick, 2009)}

At its core, Outcome Driven Innovation (ODI) is a process of identifying metrics, or outcomes, by which consumers will judge a product's value, and then systematically using them to develop products that consumers value (Ulwick, 2005). It looks to do this primarily through the application of the following three principles. 


\subsubsection{When it comes to innovation, the job, not the product, must be the unit of analysis}

\section{"People don't want to buy a quarter inch drill. They want a quarter inch hole!" - Theodore Levitt (Christensen et al., 2005)}

At the heart of ODI is the theory that consumers fundamentally 'hire' products to get jobs done. That is, whenever they use a product or service they are essentially 'hiring' it - paying with their effort, attention and other resources - in order to accomplish a task or achieve a goal (Christensen and Raynor, 2003, Christensen et al., 2005, Bettencourt and Ulwick, 2008, Ulwick, 2009, Ulwick, 2005).

For example, a consumer of a hybrid car may have a functional job of getting where they want to go quickly but with minimal environmental impact, an emotional job of feeling good that they're being environmentally conscious, and a social job to be seen by others as someone who is environmentally conscious.

Identifying the job to be done is not necessarily straightforward, as shown by an investigation into milkshakes for a large US chain: it found that the majority of consumers primarily bought milkshakes either to alleviate the boredom of a long commute to work, or to placate their children and feel they are loving parents. These findings allowed the chain to identify a range of potential improvements: to tackle

Definition: Jobs to be done, Outcomes, Constraints (Ulwick, 2005)

The jobs to be done can be defined as the fundamental goals customers are trying to accomplish or problems they are trying to solve in a given situation. They can be further subcategorised into functional jobs - the tasks people seek to accomplish, emotional jobs - the way people want to feel in a given circumstance, and social jobs - how people want to be perceived by others.

The outcomes are the metrics by which customers measure how well they are able to carry out a job using a product or service.

The constraints are the factors that may prevent a customer from adopting or using the product or service. the "boring commute" job they could swirl in chunks of fruit - meaning the consumers would at random encounter one, further breaking up the monotony of the commute - and to tackle the "looking after the child" job, they could serve it in a smaller, less viscous shake - minimising expense and avoid unduly delaying the parent while still satisfying the child (Christensen and Raynor, 2003).

\subsubsection{When the job is the unit of analysis, a need takes the form of a consumer-} defined metric

\section{"The literal voice of the customer sidetracks the innovation process because customers are not qualified to know what solutions are best - that is the job of the organization." - Anthony Ulwick (Ulwick, 2005)}

The second principle is that consumers' needs are determined not by asking consumers what they need - as they are seldom able to articulate it - but by thoroughly understanding what it is they are looking to achieve when carrying out a job. For instance, a farmer whose 
job is to grow corn may be looking to achieve outcomes such as minimising the time it takes corn seeds to germinate or maximising the number of seeds that germinate at the same time (Ulwick, 2005).

Essentially, once the job is the unit of focus, consumer needs are made clear as those things that must be measured, controlled or defined to ensure the job is executed with the speed, predictability and outputs that the consumers desire. These needs are the outcomes the consumer is looking to achieve, and the metrics by which they will evaluate a product's ability to carry out the job and hence its value (Ulwick, 2005, Ulwick and Bettencourt, 2008).

Once the metrics for a job have been identified, it is possible to systematically assess how well current or competing solutions perform, and identify opportunities for disruptive innovation where these needs are over-served, sustaining innovation where a number of key metrics are underserved, and new-market innovation where no options exist to help certain consumers complete a job (Ulwick, 2005, Christensen, 1997, Christensen and Raynor, 2003, Ulwick and Bettencourt, 2008).

\subsubsection{A job map provides the structure needed to ensure all consumer needs are captured}

The final principle of ODI is based on the observation that the majority of jobs can be broken down into a common set of process steps. It then uses these common steps as a framework to systematically identify all the outcomes consumers are looking to achieve, offering guidance for innovation opportunities at each step (Bettencourt and Ulwick, 2008, Ulwick, 2005). The steps of ODI's "universal job map" are outlined in the following table.

\begin{tabular}{|c|c|c|c|}
\hline Step & Description & $\begin{array}{l}\text { Innovation } \\
\text { opportunities }\end{array}$ & Example \\
\hline 1: Define & $\begin{array}{l}\text { Determine } \\
\text { goals and plan } \\
\text { resources. }\end{array}$ & $\begin{array}{l}\text { Simplifying } \\
\text { planning. }\end{array}$ & $\begin{array}{l}\text { Weight Watchers streamlines diet planning by } \\
\text { offering a system that doesn't require calorie } \\
\text { counting. }\end{array}$ \\
\hline 2: Locate & $\begin{array}{l}\text { Gather items } \\
\text { and } \\
\text { information } \\
\text { needed to do } \\
\text { the job. }\end{array}$ & $\begin{array}{l}\text { Making required } \\
\text { inputs easier to } \\
\text { gather and } \\
\text { ensuring they're } \\
\text { available when } \\
\text { and where } \\
\text { needed. }\end{array}$ & $\begin{array}{l}\text { U-Haul provides consumers with prepackaged } \\
\text { moving kits containing the number and types } \\
\text { of boxes required for a move. }\end{array}$ \\
\hline 3: Prepare & $\begin{array}{l}\text { Set up the } \\
\text { environment } \\
\text { to do the job. }\end{array}$ & $\begin{array}{l}\text { Making set-up } \\
\text { less difficult and } \\
\text { creating proper } \\
\text { guides to ensure } \\
\text { proper set-up of } \\
\text { the work area. }\end{array}$ & $\begin{array}{l}\text { Bosch added adjustable levers to its circular } \\
\text { saw to accommodate common bevel angles } \\
\text { used by roofers to cut wood. }\end{array}$ \\
\hline 4: Confirm & $\begin{array}{l}\text { Verify that } \\
\text { they're ready } \\
\text { to do the job. }\end{array}$ & $\begin{array}{l}\text { Giving consumers } \\
\text { information they } \\
\text { need to confirm } \\
\text { readiness. }\end{array}$ & $\begin{array}{l}\text { Oracle's ProfitLogic merchandising } \\
\text { optimization software confirms optimal timing } \\
\text { and level of a store's markdowns for each } \\
\text { product. }\end{array}$ \\
\hline
\end{tabular}




\begin{tabular}{|c|c|c|c|}
\hline 5: Execute & $\begin{array}{l}\text { Carry out the } \\
\text { job. }\end{array}$ & $\begin{array}{l}\text { Preventing } \\
\text { problems or } \\
\text { delays. }\end{array}$ & $\begin{array}{l}\text { Kimberly-Clark's Patient Warning System } \\
\text { automatically circulates heated water through } \\
\text { thermal pads placed on surgery patients to } \\
\text { maintain their normal body temperature } \\
\text { during surgery. }\end{array}$ \\
\hline 6: Monitor & $\begin{array}{l}\text { Assess } \\
\text { whether the } \\
\text { job is being } \\
\text { successfully } \\
\text { executed. }\end{array}$ & $\begin{array}{l}\text { Linking } \\
\text { monitoring with } \\
\text { improved } \\
\text { execution. }\end{array}$ & $\begin{array}{l}\text { Nike makes a running shoe containing a sensor } \\
\text { that communicates audio feedback about } \\
\text { time, distance, pace, and calories burned to an } \\
\text { iPod worn by the runner. }\end{array}$ \\
\hline 7: Modify & $\begin{array}{l}\text { Make } \\
\text { alterations to } \\
\text { improve } \\
\text { execution. }\end{array}$ & $\begin{array}{l}\text { Reducing the } \\
\text { need to make } \\
\text { alterations and } \\
\text { the number of } \\
\text { alterations } \\
\text { needed. }\end{array}$ & $\begin{array}{l}\text { By automatically downloading and installing } \\
\text { updates, Microsoft's operating systems } \\
\text { remove hassle for computer users. People } \\
\text { don't have to determine which updates are } \\
\text { necessary, find the updates, or ensure the } \\
\text { updates are compatible with their operating } \\
\text { system. }\end{array}$ \\
\hline 8: Conclude & $\begin{array}{l}\text { Finish the job } \\
\text { or prepare to } \\
\text { repeat it. }\end{array}$ & $\begin{array}{l}\text { Designing } \\
\text { products that } \\
\text { simplify the } \\
\text { process of } \\
\text { concluding the } \\
\text { job. }\end{array}$ & $\begin{array}{l}3 \mathrm{M} \text { makes a wound dressing that stretches and } \\
\text { adheres only to itself- not to patients' skin or } \\
\text { sutures. It thus offers a convenient way for } \\
\text { medical personnel to secure dressings at the } \\
\text { conclusion of treatment and then remove } \\
\text { them after a wound has healed. }\end{array}$ \\
\hline
\end{tabular}

Table 1: Job map and innovation opportunities (Bettencourt and Ulwick, 2008)

\subsubsection{Criticism of ODI}

Ulwick's views are not without criticism. Gerry Katz - Executive VP of Applied Marketing Science, Inc - has labelled them as "dangerously test[ing] the limits of generally accepted good practise" (Katz, 2008). When assessed fully, however, this criticism can be seen to revolve around rebutting Ulwick's assertion that ODI is completely different to existing Voice of the Customer techniques, as opposed to the validity of the approach itself.

"In proposing his method, Ulwick disparages several other techniques;
nevertheless, the reader should remember that techniques are often erroneously
labelled as flawed when in fact they are misapplied or poorly executed."
- Jeffrey Pinegar (Pinegar, 2006)

\subsection{Disruptive innovation}

Clayton Christensen's theory of innovation describes the ways in which new innovations can be introduced to the market, and how new market-entrants can effectively compete with larger incumbent organisations. Fundamentally, it does this by dividing innovations into two categories, described below and depicted in Figure 2.

Sustaining innovations. These are systematic innovations that improve products along key performance metrics in order to attract a quality premium from customers. In sustaining innovation, incumbent organisations are well-resourced to defend against new market entrants, meaning these new entrants will seldom be able to effectively compete. As companies tend to innovate faster than consumers' needs evolve, they risk over-serving the needs of lower-end consumers, "opening the door" to disruptive innovation by competitors (Christensen, 1997, Christensen and Raynor, 2003). 
Disruptive innovations. These are innovations that initially perform worse than existing products along a number of key performance metrics, but at much lower cost or with significantly increased simplicity or convenience - often as the result of a fundamentally new approach or technology. These innovations are typically able to capture lowperformance market niches with little difficulty, as incumbents rarely respond strongly to threats in their lower-margin operations. In many cases, these new approaches enable new entrants to rapidly enter higher-end market segments by improving performance while maintaining lower costs, until they are able to displace incumbents and come to dominate entire markets (Christensen, 1997, Christensen and Raynor, 2003).

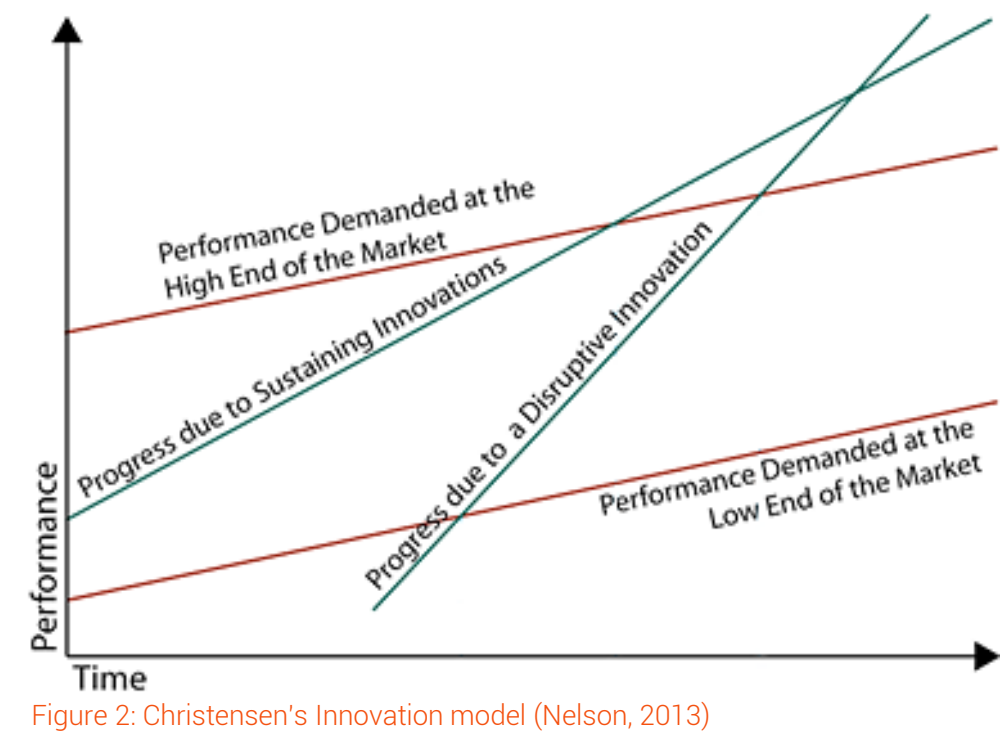

\subsection{The Lean Startup}

Eric Ries' Lean Startup methodology is rapidly being adopted by new ventures. Its central postulate is that nothing is known in a new venture's business plan; it is merely a series of hypotheses. It then defines a young venture or "start-up" as an organization searching for and validating a sustainable business model through the systematic validation of these hypotheses (Ries, 2011, Blank, 2013, Eisenmann et al., 2012, Moogk, 2012).

To do this validation, the method uses two core techniques. The first is to get "out of the building" (Blank, 2013, Ries, 2011). By this, it quite literally means that those involved with the venture should go and engage directly with potential customers in their hypothesised target market. In doing so, it aims to provide an initial test of the hypotheses in the business plan. Most importantly, it looks to validate the "value hypothesis" - that the problem or job identified is significant enough that consumers will be motivated to try, and ultimately pay for, a product that solves it.

The second method, to complete the validation of these hypotheses, is to implement the business plan through the continual use of minimally invested experiments, or minimum viable products. Behavioural consumer responses are consistently measured in each of these experiments through predetermined metrics which directly relate to business outcomes. The method then promotes rapid iteration through a build-measure-learn cycle, systematically combining successful experiments to build an organisation with a proven, sustainable business plan. 
This method offers two key advantages: it promotes customer intimacy in every stage of business development, and means that the amount invested grows only as the risk of the venture decreases.

\subsubsection{Criticism}

"You got to get the rocket into space."
- Marc Andreessen (Kern, 2012)

The Lean Startup has attracted significant criticism. But again, in the same fashion as that of ODI, this criticism is fundamentally based around the ways in which it is applied, as opposed to the methodology itself. Notable Silicon Valley VC and Entrepreneur Mark Andreessen sums up the main criticisms as falling into three categories (Kern, 2012):

1. The Lean Startup approach is not appropriate to every venture type,

2. The Lean Startup can be interpreted as de-emphasising traditional sales and marketing in the favour of product development, and

3. In promoting "fast failure" through disproving hypotheses, it promotes ventures giving up too easily.

\subsection{Summary}

In order to maximise the value it offers investors, powerHouse applies these methodologies to de-risk investments by:

- Identifying key jobs to be done by consumers, and key metrics for each of these jobs, through interaction with consumers in the target market.

- Identifying competitors by looking at other ways that consumers can complete the same job, not just directly competing products ${ }^{\text {ix }}$.

- Assessing whether existing solutions and competitors under- or over-serve consumers on any key metrics when executing the job.

- Assessing the venture's ability to satisfy these metrics comparatively.

- Sizing markets based on people needing to get certain jobs done ${ }^{x}$, and looking to invest only in opportunities where large groups of customers are struggling to get a job done.

- Launching ventures into market niches that are most under- or over- served - those with the greatest market pain

- Looking to position ventures to disrupt markets, where possible, in order to provide early revenues to support product development and to reduce competitive risk.

- Investing in small amounts, with each funding round looking to validate a key hypothesis in the business plan, e.g. the value proposition or growth strategy hypothesis.

\footnotetext{
${ }^{i x}$ For instance, by considering cellphones as competitors for watches - both address the same fundamental functional job of telling the time.

${ }^{x}$ As opposed to demographic-based market sizing, for instance.
} 


\section{Fibre-gen}

Fibre-gen is a technology company spun out by Carter Holt Harvey during their acquisition by the Rank Group in 2005. They provide acoustic instruments which allow the nondestructive measurement of wood stiffness throughout the timber supply-chain.

They have experienced some small commercial success in the subsequent years, but have recently expressed a board-level "interest" in taking on investment to finish the development of their new processor-head unit and accelerate their growth.

\subsection{Forestry industry overview}

The Forestry industry can be divided into two main groups: growers and processors. Due to the inherent variability in wood properties - between forests, between trees, and within logs - a large number of processor-types have evolved to process timber in different quality bands. High-end processors want timber which is largely knot-free, stiff, stable, and strong; low-end pulp mills have almost no quality requirements for their inbound supply. Each processor determines their own specifications, including length, for incoming logs; standard grades are rarely used.

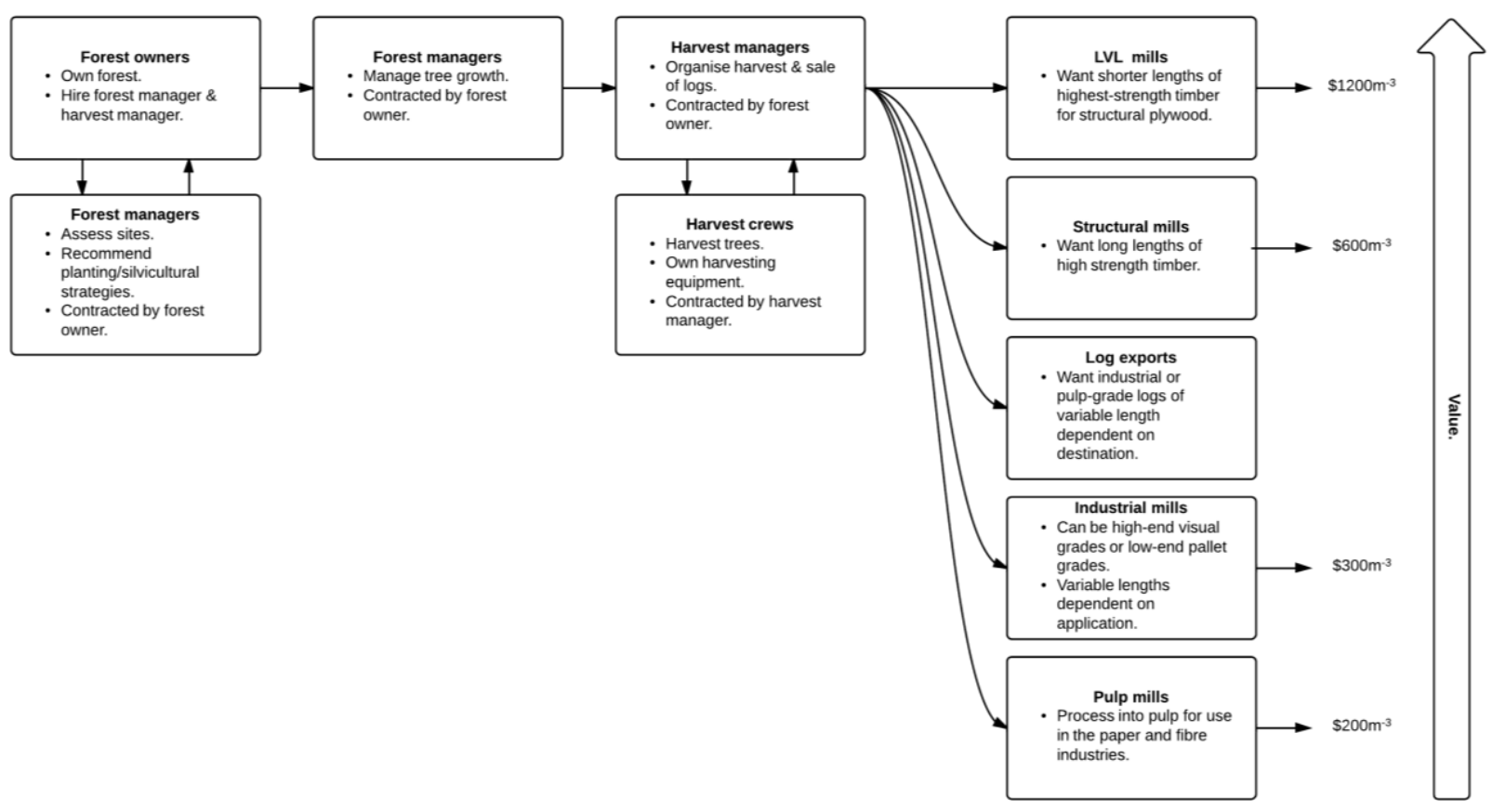

Figure 3: Forestry industry supply-chain

\section{Key wood properties (Walker, 2006)}

The properties that determine the quality of wood depend on the particular end use. Each of these is driven by a number of micro properties. The key macro-properties covering most industrial and structural end-uses are strength, stiffness, and stability.

Strength refers to the maximum load that wood can bear before rupture.

Stiffness refers to the deflection wood experiences under a given load. It is strongly correlated to strength.

Stability refers to the ability of wood to maintain its shape, especially as lumber, post -processing. Density refers to two parameters: the green density, largely driven by moisture content, and the basic or oven-dry density. The importance of density is widely misunderstood in industry. For more information see (Walker, 2006). 


\subsection{Market problem}

Approximately $10-20 \%$ of processed softwoods fail to meet the minimum requirements for the machine grading (Gardiner and Moore, 2009, Reynolds, 2010, Mochan et al., 2009) which is mandated for high-value structural timber in most jurisdictions. This is generally due to the timber failing during stress grading because it doesn't meet stiffness requirements (Gardiner and Moore, 2009, Reynolds, 2010), or because it distorts upon drying (Reynolds, 2010). Log purchasers currently base their specifications on external characteristics and knowledge of broad geographic strength trends, but still have significant variability in their supply. The worst $\sim 10 \%$ of these logs are commonly attributed with causing $\sim 90 \%$ of processing issues.

There are substantial costs associated with such downgrades; they must be sold at lower prices for non-structural uses. Currently, in NZ markets, this price differential is $\approx \$ 300 m^{-3}-a$ $50 \%$ price reduction from structural lumber ${ }^{x i}$. Operating costs are also increased since timber is transported, processed and kiln-dried before it is strength graded; energy intensive processes which can account for more than half the cost of a finished timber product (Gardiner and Moore, 2009, Visser, 2014).

\subsubsection{Job to be done}

The job to be done by Fibre-gen is to prevent variation in wood quality from negatively impacting on profits. The group currently most under-served are primary wood processors, specifically structural timber and laminated veneer lumber (LVL) mills. Their key metrics are:

- Maximising volume recovery,

- Maximising grade recovery,

- Maximising yield predictability,

- Maximising acceptable wood supply,

- Minimising the rate of timber downgrade,

- Minimising log transport distances, and

- Minimising the price paid for logs.

Their key constraint is that of additional capital investment into what is already a capitalintensive industry.

\subsection{Solution}

Fibre-gen produces tools which measure the acoustic velocity within logs and standing trees, a measurement which is strongly correlated to a number of wood quality parameters - most notably stiffness. This allows log populations to be segregated into quality classes and put to optimal end uses. These products either utilise a resonance-based velocity measure on processed logs, or a less-accurate time of flight measure for standing trees and felled stems.

Logs with a high acoustic velocity have higher average stiffness. This means they can have structural-grade lumber cut from closer to the pith of the log - which increases grade recovery - and experience lower rates of downgrade. Additionally, it allows the strong logs

\footnotetext{
${ }^{x i}$ Figure from industry interviews.
} 
in otherwise marginal forests to be identified - increasing the supply of acceptably strong logs and identifying those closest to high-end processors. Finally, by promoting more consistency in processors' feedstock, Fibre-gen increases the predictability of their yields.

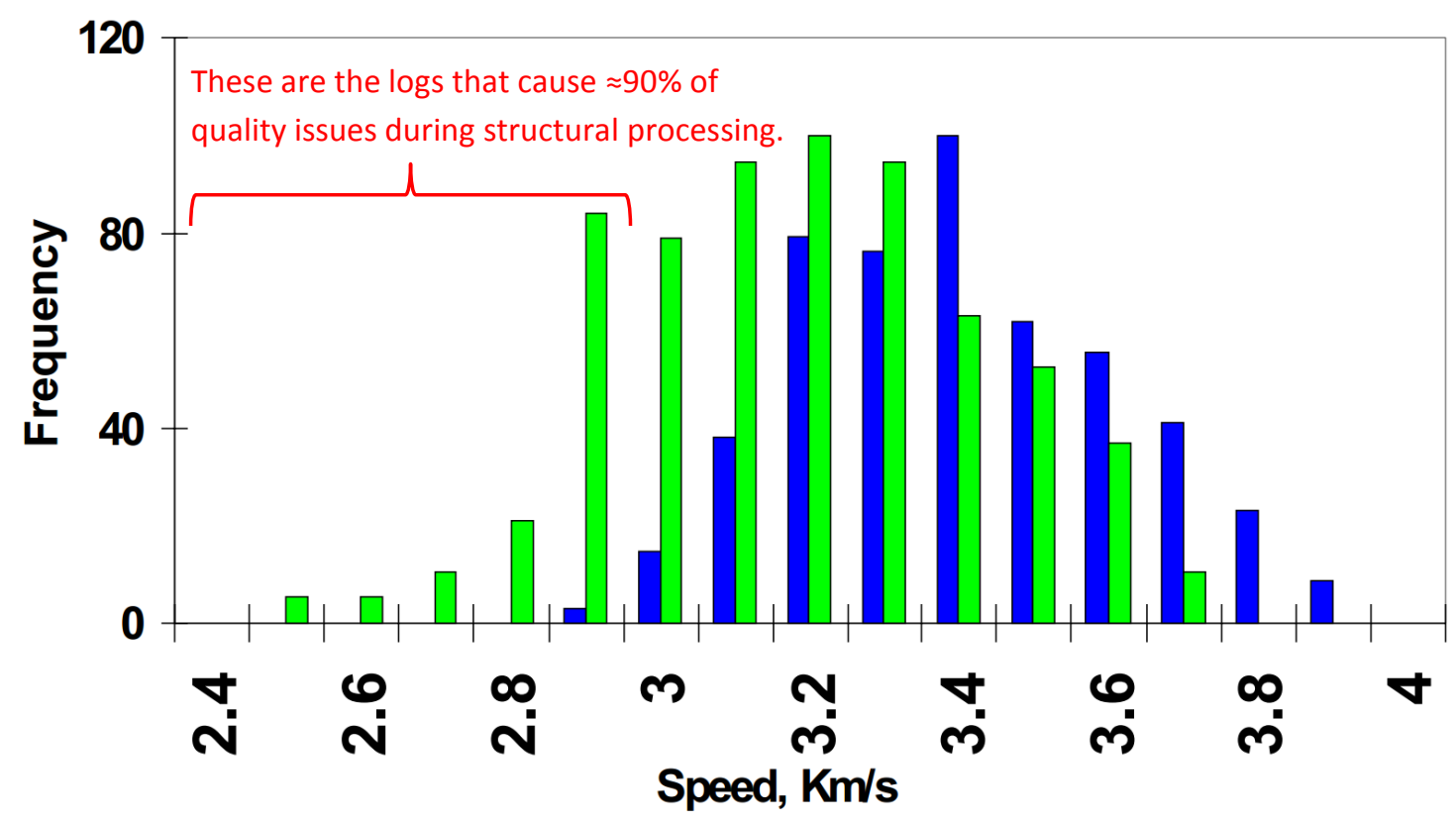

Figure 4: Acoustic velocity distribution of Radiata Pines from two stands. Figure from (Dyck, 2003).

Fibre-gen applies their acoustic technology through four products which are relevant at different stages of the supply-chain.

\begin{tabular}{|c|c|c|}
\hline Product & Price & Notes \\
\hline HM200 & $\$ 12,000$ & $\begin{array}{l}\text { Handheld unit for assessing felled trees and logs. Has had solid sales } \\
\text { of approximately } \$ 1.5 \mathrm{~m}^{\mathrm{xii}} \text { to date and is well-known in industry. } \\
\text { Value proposition (VP): Get more money for logs by matching each } \\
\text { to the highest value appropriate end-use. }\end{array}$ \\
\hline ST300 & $\$ 12,000$ & $\begin{array}{l}\text { Handheld unit for assessing standing trees. Few have been sold to } \\
\text { date. Very poor reputation in industry. } \\
\text { VP: Increase accuracy of grade yield predictions. Increase accuracy } \\
\text { of stand valuations and harvest plans. }\end{array}$ \\
\hline LG640 & $\$ 150,000$ & $\begin{array}{l}\text { Mill-based unit for assessing logs as part of the processing line. } \\
\text { Design has been licensed out to another company and is no longer a } \\
\text { focus. } \\
\text { VP: Increase recovery of high-grade timber. Reduce costs of } \\
\text { processing poor logs. }\end{array}$ \\
\hline PH330 & $\$ 88,000$ & $\begin{array}{l}\text { Processor head based unit. Development is incomplete, but believed } \\
\text { to be in its final stages. } \\
\text { VP: Make best log-making decisions e.g. if wood is structural quality } \\
\text { cut to structural length. }\end{array}$ \\
\hline
\end{tabular}

Table 2: Current Fibre-gen product line

They currently operate under a standard product-sales model. However, CEO [redacted] has mentioned moving to a service-based business model for the processor-head unit once development is complete.

xii Inferred from current annual sales of 20 unit sales per year. 
These products all represent new market innovations - before Fibre-gen released their products foresters weren't able to measure internal timber qualities in any systematic way.

Fibre-gen is able to protect this new market from competitors through a small portfolio of 3 patents in key markets - detailed in Appendix A. Several other companies produce products for acoustically measuring stiffness in an arboricultural setting, but none have the required robustness to be applied in main-stream forestry.

Fibre-gen uses no particularly rare components and outsources its manufacturing, meaning there are no likely scalability issues while operating under their sales model. Operating the Fibre-gen units under a service model may introduce scalability issues by virtue of the capital costs required to install the hardware in the initial stages.

\subsubsection{Processor-head unit (PH330)}

It was concluded that most of Fibre-gen's potential lies in the PH330, primarily as a result of its position at the start of the supply-chain and its potential to access a much larger market through a service model. This view is echoed by Fibre-gen management. It offers value to both harvesters and processors. To harvesters it means they can use stiffness information to optimise their log-making decisions and segregate all logs into quality classes as they are cut, to be sold separately. To log processors it offers a more consistent, segregated supply; a proposition particularly appealing to LVL mills which struggle to find the high-strength logs they require amongst the domestic log supply.

The PH330 has gone through 5 major validation studies, which have proven the concept but raised issues with the accuracy of the stiffness measured compared to that of the HM200. This is primarily a result of the fact that it is limited to the less-accurate time of flight approach. Recent studies have shown that this accuracy could be improved by including physical log parameters, already measured by the processor heads, into the model. Work is ongoing to incorporate these into the unit, and some work remains to improve its robustness. Some external funding and support may be available from Scion and the Wood Quality Initiative to continue development.

\subsection{Current ownership}

"Fibre-gen" consists of three legal entities: an IP holding entity, a holding company, and an operating company. [Redacted] and [redacted] have significant interests in each of these. Four other minority shareholders make up the balance. The current ownership structure is given as Appendix A.

[Redacted]. 


\subsection{Key people}

[Redacted]

\subsection{Market}

\subsubsection{Size}

Operating under their current sales model it is estimated that the domestic addressable market for Fibre-gen is NZ\$1.5m annually, and NZ\$150m globally.

Operating under the proposed service model it is estimated that the domestic addressable market for the Fibre-gen unit would be NZ\$4m annually, and NZ\$400m globally.

Details of these size calculations are given as Appendix C.

\subsubsection{Dynamics}

Most mills are able to identify poor performing log suppliers or forests retrospectively and just avoid buying from them again. Millers pride themselves on their experience that allows them to do this - meaning they are reluctant to use tools which imply their judgement is insufficient.

Even fast-grown timber typically has a crop life of 25 years. This means that wood supply is essentially fixed at any point in time. To increase revenues wood growers can only look to identify and recover the value that is in the trees that they have. This is driving uptake of automation and electronic optimisation technologies.

The price premium commanded by high strength logs is rapidly diminishing. This is deemed unlikely to simply be a result of the global financial difficulties - it is caused by disproportionate increases in price for low-end logs which precede these difficulties. The likely driver of this is the "China Effect": an extreme demand for logs for low-end end uses which has almost completely eroded the price premium for structural logs, demonstrated by the figure below.

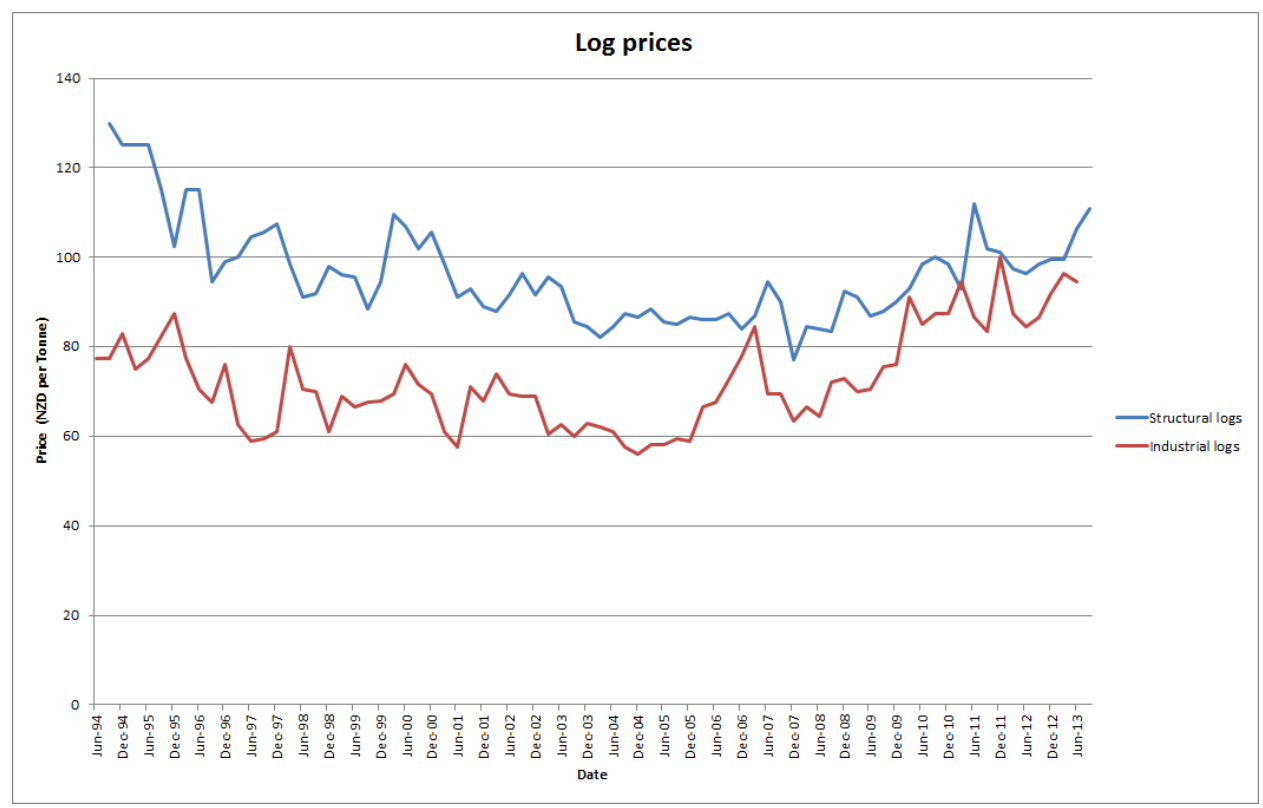

Figure 5: New Zealand Log Prices (New Zealand Ministry for Primary Industries, 2013). 
Decreases in rotation age of plantation timber are causing decreases in average quality levels and increases in variability.

Demand for timber is increasingly becoming more for its fibre-content, for use in remanufacturing, as opposed to traditional lumber products. This is further driving up demand for lower quality timber, reducing the price premium for quality timber.

\subsection{Concerns with current model}

There are a number of areas of concern for Fibre-gen as an investment opportunity in its current form. There are four main contributors to this:

- A modest globally addressable market - meaning high levels of market penetration will be required to achieve desirable revenues;

- The lack of a clear customer - their technology offers significant benefits to the industry as a whole, but the value proposition to any one entity is limited meaning there are few willing to pay;

- The erosion of the price premium commanded by structural logs - Fibre-gen's value proposition fundamentally relies on the ability to sell higher strength logs for a significant premium, which is no longer the case in many large markets; and

- In order for Fibre-gen to represent an attractive opportunity, powerHouse's investment would need to facilitate rapid growth; it is difficult to see what investment by powerHouse could fundamentally change to deliver this growth.

\subsection{Summary}

Fibre-gen has developed effective tools to salve what appears to be a significant market pain $-10 \%$ yield losses and poor process control. However, market interaction has revealed there is little market pull for Fibre-gen's products; customers appear happy accept these largely unrealised losses as a natural part of their industry.

The reasons for this can be seen to be largely outside Fibre-gen's sphere of influence, factors well-described by PEST analysis: politically, the 2008 Free Trade Agreement exposed New Zealand's log supply to the vast demand presented by a rapidly developing China, driving up the demand and price for low-quality logs; economically, the 2007 financial crisis supressed new residential construction in key international markets, reducing the demand and price for high-quality logs; and technologically, recent advances in wood manufacturing techniques have disproportionately increased the demand and price for low-quality logs as a fibre-source for remanufacturing.

The result is a market in which log prices are high and largely unaffected by quality. This means wood growers are scarcely motivated to use Fibre-gen's tools as logs already fetch good prices, and there is little premium to be gained from identifying high-quality logs. For wood processors, on the other hand, the high log-price means they are unwilling to demand the use of Fibre-gen's tools to avoid paying any more for logs. This, combined with the natural inertia of the status quo, has significantly eroded Fibre-gen's value-proposition, making it extremely difficult for the business to flourish. 
It should be noted that changes in the global market continue to occur, meaning this may change in future. However, as it is almost impossible to accurately predict these changes, any reliance on them to predicate an investment decision would carry a high degree of risk.

\title{
5. WoodCoxiii
}

\author{
For timber processors struggling to optimise value recovery, \\ WoodCo demonstrates timber's true quality, \\ allowing them to avoid those $10 \%$ of logs that cause $90 \%$ of problems. \\ Unlike external measurements and rules of thumb, WoodCo describes timber as it \\ is, not how it looks. \\ - WoodCo Positioning Statement
}

While it appears Fibre-gen may not represent an attractive investment as they are, it is believed that the incorporation of their technologies with others under the banner of "WoodCo" will overcome the aforementioned issues and represent an attractive investment.

WoodCo aims to be the defining source of timber quality. It will do this by measuring a range of timber quality attributes from the point of harvest, tracking these against each individual log, and using this information to help optimise wood-flow throughout the whole supply-chain. The system proposed is illustrated overleaf, with specific technology sources identified in Appendix E.

xiii "WoodCo" is used as a temporary name to talk about the proposed venture. 
5.1 Proposed WoodCo system overview

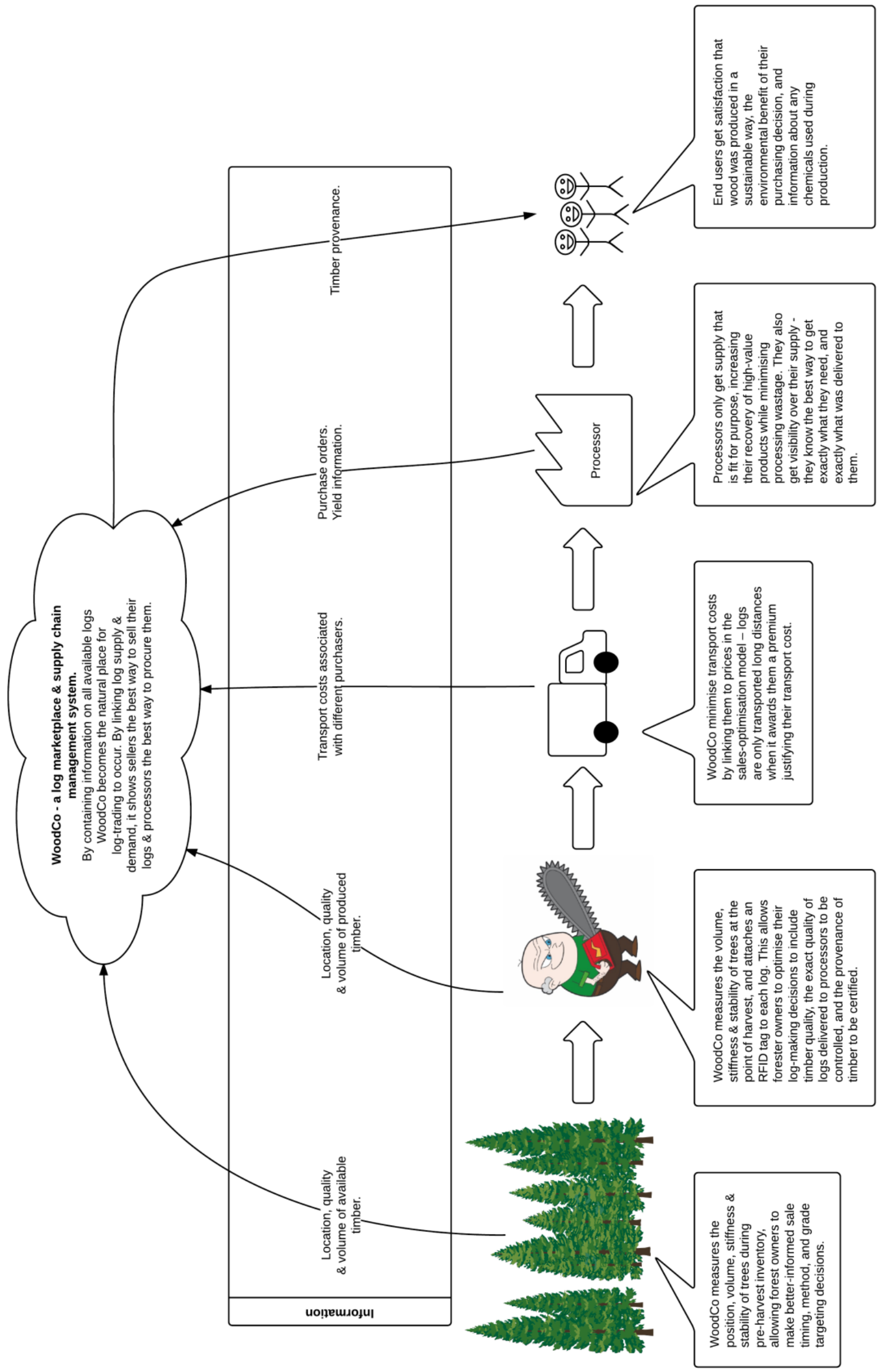




\subsection{Value proposition hypotheses}

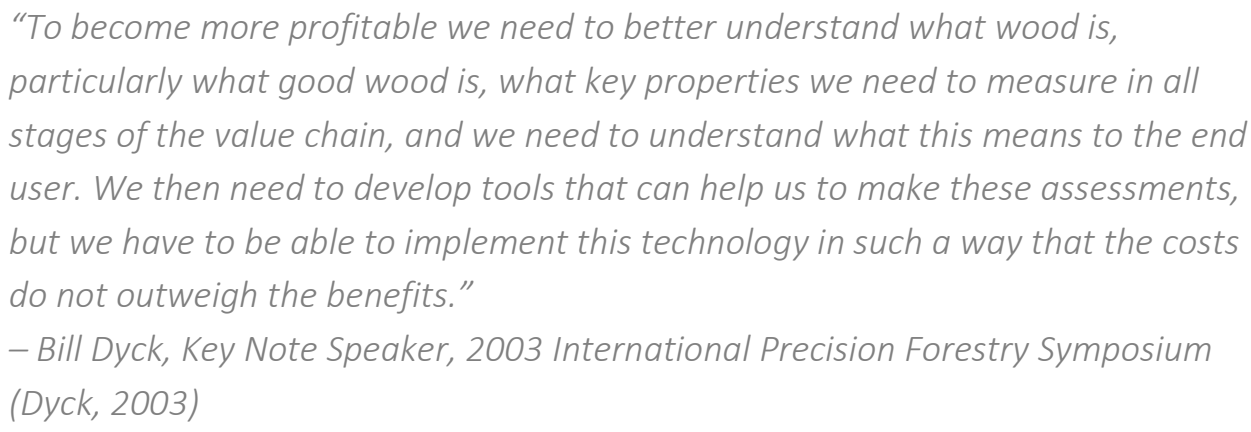

The most compelling proposition is that offered to timber processors. However, to deliver this, the system must be applied early in the supply-chain, hence it must also offer compelling value propositions to the harvesters and harvest managers to motivate system uptake by these parties.

\begin{tabular}{|c|c|}
\hline Group & Value proposition hypothesis \\
\hline Forest owners & $\begin{array}{l}\text { Optimise returns by balancing transport costs against available log } \\
\text { prices. }\end{array}$ \\
\hline $\begin{array}{l}\text { Harvesters and } \\
\text { harvest managers }\end{array}$ & $\begin{array}{l}\text { Sell logs more easily by being able to demonstrate their quality. } \\
\text { Increase value offered to forest owners by optimising value } \\
\text { recovery. }\end{array}$ \\
\hline $\begin{array}{l}\text { Timber } \\
\text { processors }\end{array}$ & $\begin{array}{l}\text { Increase grade recovery and predictability by only processing } \\
\text { appropriate logs. } \\
\text { Increase accessibility of supply by identifying all acceptable logs. } \\
\text { Reduce wastage due to warping by removing warp-prone logs from } \\
\text { supply. } \\
\text { Reduce wasted processing costs by increasing the accuracy of grade } \\
\text { recovery. }\end{array}$ \\
\hline End users & $\begin{array}{l}\text { - Quantify the environmental benefit of purchasing a timber product. } \\
\text { Demonstrate the sustainability and legality of timber products' } \\
\text { production. } \\
\text { Demonstrate if chemicals of concern have been used in the } \\
\text { production of a timber product. }\end{array}$ \\
\hline
\end{tabular}

Table 3: Value proposition hypotheses

\subsection{Business model hypotheses}

As the value offered by WoodCo is ultimately realised by wood processors, they are believed to be the ultimate customer. As a result of their capital constraints, particularly for untested products, a service-based business model appears to be the most appropriate. The proposed service model is shown in the following figure. 


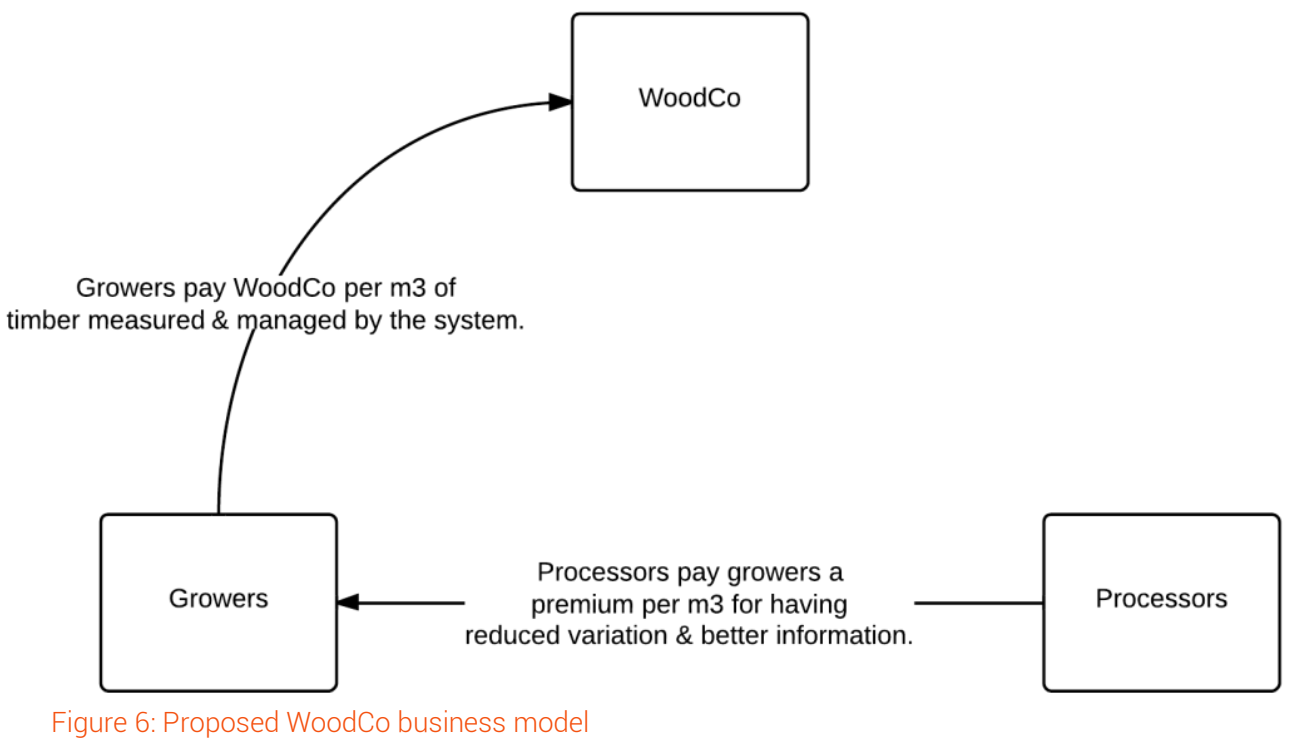

It is suggested that the amount charged be linked to the quality of the timber as measured by WoodCo. This maximises the systems relevance across the variable resource, spreads the capital cost of providing the hardware over the largest possible revenue stream, minimises the barriers processors face to adopt the system, and provides WoodCo with sustainable, repeating revenues.

\subsection{Launch market}

The launch market would be measuring the stiffness of logs using the Fibre-gen PH330 technology. This has an estimated annual addressable market of NZ\$4m annually within New Zealand, and NZ\$400m globally. These calculations are shown in Appendix C.

WoodCo is particularly well suited to the New Zealand market as the dominant species, the Radiata Pine, exhibits particularly significant variation in its mechanical properties, with average stiffness values lower than those required for high-value structural lumber production.

\subsection{Growth hypothesis}

WoodCo will begin by measuring stiffness at the point of harvest for each log. It will target Structural and LVL processors through the use of quantified benefit models. This will allow the development of relationships and channels through which further developments can be deployed.

It will then develop and implement the RFID tagging system. This will allow quality attributes to be traced against each log, and provide the data necessary for the development of log trading, tracking and transport optimisation functionalities. The development of these will expand the globally addressable market to an estimated figure of NZ\$800m annually ${ }^{\text {xiv }}$.

\footnotetext{
${ }^{\text {xiv }}$ This is a very high-level, top down estimate which was necessitated by time constraints. Details of the calculation are included in Appendix C.
} 
Once this platform is developed, additional sensors for measuring the stability of logs can be added. This would be expected to increase the globally addressable market to an estimated $N Z \$ 1.2 b$ annually ${ }^{x v}$.

\subsection{Exit strategy}

Exit for a company of this type would typically be as via trade sale to a large company in the Forestry market. A number of large companies, most notably Trimble, John Deere and Komatsu are actively acquiring in this space, however it should be noted that companies are typically well-established before acquisition.

It is believed that WoodCo would represent an attractive acquisition for these companies for a number of reasons, mainly:

- It is somewhat analogous to Asset Forestry Ltd, a Christchurch-based producer of forestry logistics systems, which was acquired by Trimble in 2013 for an undisclosed sum;

- It is in line with the growth strategy intimated by the New Zealand Waratah (owned by John Deere) sales rep, where they see their growth coming through the increased utilisation of sensors to inform processor-head bucking optimisation models; and

- It is in line with broader acquisition trends towards integrated industry-wide optimisation systems and the integration of sensors into these.

Large players and an analogous deal can be found in Appendix G.

\subsection{Key assumptions}

While the work done to date suggests that WoodCo presents an attractive investment, a number of key assumptions remain to be validated. These include that:

- Fibre-gen technology can be licensed in.

- Timber processors earn a significant premium for high-quality products in all major markets.

- RFID technology can be obtained, and cost-effectively and reliably applied in practise.

- Stability can be measured accurately on a log by log basis in-field.

- Timber harvesters will be willing to physically segregate different log classes.

- This model is equally applicable in large foreign markets (e.g. those with slower grown forests).

- Uptake will be fast enough to overcome the network effect inherent in the model.

- Freedom to operate exists or can be acquired in each of the functional areas.

- Fibre-gen patents are strong and enforceable in all key international markets (particularly South American, North American and European markets).

- Log processors consider measuring every log, as opposed to samples of logs, valuable.

\footnotetext{
${ }^{x v}$ Likewise.
} 
- Low-end lumber prices will not be increased as a result of increased demand from engineered wood product manufacturers e.g. CLT.

- The benefit to processors can be quantified.

- Sale/supply contracts in industry can be changed to include premiums for quality timber.

\subsection{Summary}

\section{"[There is a] broken chain from forest to building industry" - Professor Robert Kliger ${ }^{x v i}$}

By representing timber as a digital entity through the use of established RFID technologies, WoodCo presents the opportunity to apply the full power of information technology to the Forestry industry. By combining this with proprietary measurement technologies, WoodCo presents an opportunity to provide the Forestry industry with insight previously considered impossible.

To wood growers it presents the opportunity to maximise the return provided by their forests, not just the revenue. To timber processors it presents the opportunity to gain the control and visibility of their supply that they require to gain control of their outputs. Finally, to consumers rapidly demanding more sustainably \& ethically produced goods, WoodCo provides visibility of their provenance.

By offering value less sensitive to market fluctuations, WoodCo is able to overcome those market forces currently impacting on Fibre-gen, and is well-placed to capitalise should those forces abate.

Finally, by offering value to a large and well-established market, and with indications of significant acquisition interest, WoodCo presents an attractive opportunity not only as a business, but as an investment.

\section{Conclusions}

Fibre-gen appears to have been the unfortunate victims of market risk: the market rapidly changed after their spin-out, with factors outside of their control eroding their value proposition to key parties in the supply-chain. As a result, it appears that Fibre-gen does not present an attractive investment opportunity in its current form. It is noted that changes in market conditions may change this, however, these are impossible to accurately predict.

A significant difference between the perspectives of industry and academia was noted during the project. Whilst academics regularly apply sophisticated approaches to improving forestry performance, the prevailing view in industry is one of scepticism towards these approaches - resulting in an industry preference for innovations in the form of bigger, better versions of current tools; not fundamentally different approaches. To overcome this any new technology-based venture must prioritise an apparent simplicity to users, and take

\footnotetext{
${ }^{x v i}$ Attributed in MOORE, J. R. 2012. Growing Fit-For-Purpose Structural Timber: What's the Target and How Do We Get There? NZ Journal of Forestry, 57.
} 
care to down-play the technical aspects of their products in favour of a focus on the job it does for foresters in terms they understand and can relate to.

Finally, there is no doubt that the variability inherent in commercial Forestry is poorly managed, and compounded by the fact that information flow through the supply-chain is also poor. Therefore, there is definitely a commercial opportunity to be found in providing the means to better manage this variability. In the words of Professor Robert Kliger, Professor of Structural Engineering at Chalmers University, there is a "broken chain from forest to building industry". The opportunity is for WoodCo to fix this chain.

\section{Recommendations}

Based on the work performed it is recommended that powerHouse:

Continue building a formal investment case for a company, WoodCo, that licenses in Fibregen's acoustic and processor-head platform IP to be combined with tracking and other measurement technologies. This should look to involve industry experts and validate the assumptions listed in section 5.7 as early as possible.

Grow relationship with Scion. Scion is New Zealand's leading Forestry research institution. It works on a number of different projects and is making moves to increase commercialisation activities as part of its ongoing strategy, making it a natural fit for partnership with powerHouse.

Investigate telematics research occurring at UC. This research is looking to enable remotelyoperated logging activities. By allowing work to be performed remotely, removing people from the forest floor, this begins to offer a solution to the industry's most pressing pain: that their people keep getting hurt and killed. There is no question the industry is moving towards this.

\section{Statement of personal value}

This project was much harder than I anticipated. Whilst a lot of the theoretical aspects are easily stated and understood, their practical application has been the single largest challenge of my MEM. I think for that reason alone, the project has been immensely valuable. A number of key lessons were also learnt. The following table documents these, both to demonstrate the amount gained by the student, and to serve as an aide to those undergoing similar projects in future. 


\begin{tabular}{|c|c|c|c|c|}
\hline Category & Issue & Problem/success & Impact & Resolution/recommendation \\
\hline General. & Overworking. & $\begin{array}{l}\text { A significant amount of extra work } \\
\text { was carried out concurrently to } \\
\text { this project, both related and } \\
\text { unrelated to the MEM. In } \\
\text { attempting to keep up with this, I } \\
\text { worked a significant number of } \\
\text { consecutive } 12+\text { hour days and } \\
\text { weekends. }\end{array}$ & $\begin{array}{l}\text { While at the time I felt that this } \\
\text { was merely a case of working } \\
\text { hard, it is apparent in hindsight } \\
\text { that my hourly productivity was } \\
\text { significantly impaired, meaning } \\
\text { that had I enjoyed more breaks } \\
\text { and given myself more time off, I } \\
\text { likely would have achieved the } \\
\text { same results in a reduced } \\
\text { timeframe. }\end{array}$ & $\begin{array}{l}\text { Always be aware of looking after } \\
\text { the 'human-factors' of projects, } \\
\text { even when it appears that time to } \\
\text { do so is a luxury which is not } \\
\text { available. Additionally, while much } \\
\text { of the work was unavoidable (e.g. } \\
\text { moving house) had a longer term } \\
\text { view been taken during my } \\
\text { planning it would have been } \\
\text { possible to spread some of the } \\
\text { workload over a longer period. } \\
\text { Such a long-term view should be } \\
\text { taken in future projects. }\end{array}$ \\
\hline General. & $\begin{array}{l}\text { Diminishing } \\
\text { returns. }\end{array}$ & $\begin{array}{l}\text { When looking into Fibre-gen's } \\
\text { products, wood quality and value } \\
\text { chain issues I found myself } \\
\text { reading a lot of papers to deepen } \\
\text { my understanding of the } \\
\text { technology and the industry. }\end{array}$ & $\begin{array}{l}\text { In hindsight it's clear that much of } \\
\text { this time was wasted as, while } \\
\text { useful for developing my } \\
\text { understanding of the industry, } \\
\text { much of the detail I was } \\
\text { uncovering added little value to } \\
\text { the investment case. }\end{array}$ & $\begin{array}{l}\text { Be mindful of diminishing returns } \\
\text { during future work. It was good to } \\
\text { have learnt this early on in the } \\
\text { project. }\end{array}$ \\
\hline General & $\begin{array}{l}\text { Researching in } \\
\text { the real world. }\end{array}$ & $\begin{array}{l}\text { In market sizing there were a } \\
\text { number of data-points which } \\
\text { were required but could not be } \\
\text { easily identified. Where for } \\
\text { academic research they could } \\
\text { often be either assumed or left } \\
\text { unknown, in this case they were } \\
\text { required. }\end{array}$ & $\begin{array}{l}\text { This meant it was necessary to } \\
\text { think laterally to find proxies for } \\
\text { each data point, and use different } \\
\text { kinds of research tools (e.g. site- } \\
\text { indexed searches from multiple } \\
\text { providers) to dig out the } \\
\text { information. }\end{array}$ & $\begin{array}{l}\text { Utilise advanced search } \\
\text { techniques to find required } \\
\text { information. If information still } \\
\text { cannot be found then look to find } \\
\text { sensible proxies. }\end{array}$ \\
\hline
\end{tabular}




\begin{tabular}{|c|c|c|c|c|}
\hline General. & $\begin{array}{l}\text { The importance } \\
\text { of networks. }\end{array}$ & $\begin{array}{l}\text { When beginning to analyse Fibre- } \\
\text { gen I completely lacked any } \\
\text { information about its context. }\end{array}$ & $\begin{array}{l}\text { By utilising several contacts of } \\
\text { powerHouse staff I was able to } \\
\text { quickly get the input of people } \\
\text { with significant knowledge of the } \\
\text { forestry industry. }\end{array}$ & $\begin{array}{l}\text { Do not underestimate the power } \\
\text { of networks and utilise them more } \\
\text { effectively. }\end{array}$ \\
\hline General. & $\begin{array}{l}\text { The importance } \\
\text { of proper } \\
\text { documentation. }\end{array}$ & $\begin{array}{l}\text { In the market-sizing there were a } \\
\text { number of implicit assumptions. } \\
\text { Both to identify them for later } \\
\text { testing and to demonstrate the } \\
\text { validity of the sizing it was } \\
\text { necessary to document clearly \& } \\
\text { concisely where each figure in the } \\
\text { model came from and why they } \\
\text { were processed the way they } \\
\text { were. }\end{array}$ & $\begin{array}{l}\text { This allowed others to more easily } \\
\text { peer review work, and allowed me } \\
\text { to ensure I had identified all key } \\
\text { assumptions. }\end{array}$ & $\begin{array}{l}\text { Ensure that work performed is } \\
\text { properly documented. Do not } \\
\text { omit this when subject to time } \\
\text { pressure. }\end{array}$ \\
\hline Commercialisation. & $\begin{array}{l}\text { Talking to } \\
\text { customers. }\end{array}$ & $\begin{array}{l}\text { Talking to customers gets spoken } \\
\text { about a lot and I felt pretty } \\
\text { comfortable with the idea in } \\
\text { theory, but in reality I was } \\
\text { surprised at how reluctant I was } \\
\text { when it came time to actually get } \\
\text { out from behind the desk. Once I } \\
\text { did, I was impressed by the insight } \\
\text { that they gave me into the issues } \\
\text { they face and the industry, and } \\
\text { also how passionate they became } \\
\text { when asked about the } \\
\text { hypothesised problem. }\end{array}$ & $\begin{array}{l}\text { Significantly improved the insight } \\
\text { gained into Fibre-gen and the } \\
\text { Forestry industry. }\end{array}$ & $\begin{array}{l}\text { Always ensure that customers are } \\
\text { intimately involved through non- } \\
\text { structured interactions. }\end{array}$ \\
\hline
\end{tabular}




\begin{tabular}{|c|c|c|c|c|}
\hline Commercialisation. & Sizing markets. & $\begin{array}{l}\text { When it came time to size } \\
\text { markets for Fibre-gen I had no } \\
\text { idea how to approach the } \\
\text { problem. }\end{array}$ & $\begin{array}{l}\text { Had to think laterally and find a } \\
\text { way to reasonably estimate the } \\
\text { market sizes using a bottom-up } \\
\text { approach. }\end{array}$ & $\begin{array}{l}\text { Think laterally to construct } \\
\text { bottom-up market models in } \\
\text { whichever way seems reasonable. } \\
\text { Use proxies where necessary and } \\
\text { "sanity checks" wherever possible. } \\
\text { List all assumptions made in } \\
\text { constructing the model. }\end{array}$ \\
\hline Commercialisation. & $\begin{array}{l}\text { Non-financial } \\
\text { outcomes. }\end{array}$ & $\begin{array}{l}\text { In identifying who would actually } \\
\text { pay for more information in the } \\
\text { wood value chain it was difficult } \\
\text { to identify who would financially } \\
\text { benefit from it, i.e. who would be } \\
\text { the customer. }\end{array}$ & $\begin{array}{l}\text { It was necessary to consider both } \\
\text { financial \& non-financial } \\
\text { outcomes when looking at } \\
\text { benefits, eg who makes more } \\
\text { money as a result of the } \\
\text { information and whose job is } \\
\text { made easier? }\end{array}$ & $\begin{array}{l}\text { Look at both financial and non- } \\
\text { financial benefits that products } \\
\text { and services offer. }\end{array}$ \\
\hline Commercialisation. & $\begin{array}{l}\text { Identifying } \\
\text { needs. }\end{array}$ & $\begin{array}{l}\text { It was difficult to assess the } \\
\text { informational needs of the } \\
\text { forestry industry. }\end{array}$ & $\begin{array}{l}\text { Use ODI and the job map as a } \\
\text { framework for identifying ways in } \\
\text { which a job could be made easier. } \\
\text { This made identifying the } \\
\text { information needs of the forestry } \\
\text { industry significantly easier. }\end{array}$ & $\begin{array}{l}\text { Use ODI principles when assessing } \\
\text { customer needs. }\end{array}$ \\
\hline
\end{tabular}

Ultimately this project has made for an excellent introduction to the real world, given me both insight and a head-start into the career I want to lead, and I like to think it has left me significantly less naïve than the wide-eyed student that began the project. 


\section{References}

AARONS-MELE, M. 2014. The Dangerous Rise of "Entrepreneurship Porn". Harvard Business Review. ADAMS, R. 2002. A Good Hard Kick in the Ass: Basic Training for Entrepreneurs, Crown Business.

ADAMS, R. 2010. If You Build It Will They Come: Three Steps to Test and Validate Any Market Opportunity, Wiley.

BELL, G. 2000. Entrepreneurial Ventures: How do you do them? : Microsoft Research.

BETTENCOURT, L. A. \& ULWICK, A. 2008. The Customer-Centred Innovation Map. Harvard Business Review.

BLANK, S. 2013. Why the Lean Startup Changes Everything. Harvard Business Review.

CHRISTENSEN, C., COOK, S. \& HALL, T. 2005. Marketing Malpractice: The Cause and the Cure. Harvard Business Review.

CHRISTENSEN, C. M. 1997. The Innovator's Dilemma: When New Technologies Cause Great Firms to Fail, Harvard Business School Press.

CHRISTENSEN, C. M. \& RAYNOR, M. E. 2003. The Innovator's Solution: Creating and Sustaining Successful Growth, Harvard Business School Press.

DAMODARAN, A. 2009. Valuing young, start-up and growth companies: estimation issues and valuation challenges. Available at SSRN 1418687.

DAMODARAN, A. 2012. Relative Valuation and Private Company Valuation. Stern School of Business, New York Univesrity.

DUNNE-SCHMITT, E. 2004. Economics 342 Banking \& Financial Markets Lecture Notes. New York: SUNY Oswego.

DUSHNITSKY, G. \& SHAVER, J. M. 2009. Limitations to interorganizational knowledge acquisition: the paradox of corporate venture capital. Strategic Management Journal, 30, 1045-1064.

DYCK, B. Precision Forestry - The Path to Increased Profitability! . In: COOKE, A., ed. The second international precision forestry symposium, 2003 Seattle, Washington.

EISENMANN, T., RIES, E. \& DILLARD, S. 2012. Hypothesis-Driven Entrepreneurship: The Lean Startup. Harvard Business School Entrepreneurial Management Case.

GARDINER, B. \& MOORE, J. 2009. Implications for Forecasting Stiffness. UK Forestry Commission.

GE, D., MAHONEY, J. M. \& MAHONEY, J. T. 2005. New venture valuation by venture capitalists: an integrative approach. University of Illinois at Urban Champaign Working Paper, 124, 05-0124.

GRINSTEAD, C. M. \& SNELL, J. L. 1997. Introduction to Probability, American Mathematical Society.

HEALY, P. M. \& PALEPU, K. G. 2001. Information asymmetry, corporate disclosure, and the capital markets: A review of the empirical disclosure literature. Journal of accounting and economics, 31, 405-440.

KAHNEMAN, D. 2011. Thinking, Fast and Slow, Farrar, Straus and Giroux.

KAHNEMAN, D. \& TVERSKY, A. 2000. Choices, Values, and Frames, Cambridge University Press.

KAPLAN, S. N. \& STRÖMBERG, P. 2003. Financial contracting theory meets the real world: An empirical analysis of venture capital contracts. The Review of Economic Studies, 70, 281-315.

KATZ, G. 2008. A Critique of Outcome-Driven Innovation. Applied Marketing Science Inc.

KERN, E. 2012. Marc: Andreessen: Not Every Startup Should be a Lean Startup or Embrace the Pivot [Online]. www.gigaom.com. Available: http://gigaom.com/2012/12/03/marc-andreessen-notevery-startup-should-be-a-lean-startup-or-embrace-the-pivot/.

KUT, C., PRAMBORG, B. \& SMOLARSKI, J. 2007. Managing financial risk and uncertainty: The case of venture capital and buy-out funds. Global Business and Organizational Excellence, 26, 53-64.

LO, A. 2001. Risk management for hedge funds: Introduction and overview. Available at SSRN 283308. LOY, T. 2013. Structuring Venture Capital Investment. Stanford University.

MAUBOUSSIN, M. 2005. Attributes of a Good Investment Process - The Critical Role of Decision Making. In: SUNDER, S. (ed.) Yale School of Managament Lecture Series. Yale University: Legg Mason Capital Management. 
MOCHAN, S., MOORE, J. \& CONNOLLY, T. 2009. Using Acoustic Tools in Forestry and the Wood Supply-chain. UK Forestry Commission.

MOOGK, D. R. 2012. Minimum Viable Product and the Importance of Experimentation in Technology Startups. Technology Innovation Management Review.

MOORE, J. R. 2012. Growing Fit-For-Purpose Structural Timber: What's the Target and How Do We Get There? NZ Journal of Forestry, 57.

NELSON, D. 2013. The Decline of Innovation and the Resurgence of Incrementalism. Innovation Crescendo [Online]. Available from: http://innovationcrescendo.com/2013/04/08/thedecline-of-innovation-and-the-resurgence-of-incrementalism/.

NEW ZEALAND MINISTRY FOR PRIMARY INDUSTRIES 2013. Log Price Series. In: NEW ZEALAND MINISTRY FOR PRIMARY INDUSTRIES (ed.). http://www.mpi.govt.nz/newsresources/statistics-forecasting/forestry/indicative-new-zealand-radiata-pine-log-prices.aspx.

NOBEL, C. 2011. Why Companies Fail--and How Their Founders Can Bounce Back. Harvard Business School Working Knowledge. Harvard Business School.

PAYNE, B. 2013. Methods for Valuation of Seed Stage Startup Companies [Online]. Angel Capital Association: Angel Capital Association. Available: http://www.angelcapitalassociation.org/blog/methods-for-valuation-of-seed-stage-startupcompanies/.

PAYNE, W. H. 2007a. Fundability and Valuation of Startups: An Angel's Perspective. Valuing Prerevenue Companies http://www.angelcapitalassociation.org/: Ewing Marion Kauffman Foundation.

PAYNE, W. H. 2007b. Valuation of Pre-revenue Companies: The Venture Capital Method. Valuing Prerevenue Companies. http://www.angelcapitalassociation.org/: Marion Ewing Kauffman Foundation.

PINEGAR, J. S. 2006. What Customers Want: Using Outcome-Driven Innovation to Create Breakthrough Products and Services by Anthony W. Ulwick. Journal of Product Innovation Management, 23, 464-466.

RANADE, V. 2008. Early-Stage Valuation in the Biotechnology Industry. The Walter H. Shorenstein Asia-Pacific Research Center, Stanford University.

REYNOLDS, T. N. 2010. Variables affecting the stiffness and distortion of Sitka spruce. Edinburgh Napier University.

RIES, E. 2011. The Lean Startup: How Today's Entrepreneurs Use Continuous Innovation to Create Radically Successful Businesses, Crown Business.

ROBERTS, M. \& BARLEY, L. 2005. Four VCs on Evaluating Opportunities [Online]. Working Knowledge: Harvard Business School. Available: http://hbswk.hbs.edu/item/4780.html.

ROSENMAN, R. 2013. Uncertainty and Expected Value [Online]. Available: http://faculty.ses.wsu.edu/rosenman/dist-managerial/uncertainty and expected value.htm.

SAHLMAN, W. 2009. The Basic Venture Capital Formula. Harvard Business School.

SAMUELSON, P. A. 1963. Risk and Uncertainty: A Fallacy of Large Numbers. Scientia.

SCHNEIDER, J. \& HALL, J. 2011. Why Most Product Launches Fail. Harvard Business Review.

SHARPE, W. F. 2007. Expected utility asset allocation. Financial Analysts Journal, 18-30.

THURSTON, T. 2013. Disrupting Venture Capital. Thunderbird International Business Review, 55, 115120.

ULWICK, A. 2005. What Customers Want, McGraw-Hill Education (India) Pvt Limited.

ULWICK, A. 2009. An Introduction to Outcome-Driven Innovation. Strategyn, Inc.

ULWICK, A. \& BETTENCOURT, L. 2008. Giving Customers a Fair Hearing. Sloan Management Review.

VILLALOBOS, L. 2007. Investment Valuations of Seed- and Early-Stage Ventures. Valuing Pre-revenue Companies. http://www.angelcapitalassociation.org/: Marion Ewing Kauffman Foundation.

VISSER, R. 5/02/2014 2014. RE: Interview.

WALDRON, D. \& HUBBARD, C. M. 1991. Valuation Methods and Estimates in Relationship to Investing Versus Consulting. Entrepreneurship: Theory \& Practice, 16, 43-52. 
WALKER, J. C. F. 2006. Primary Wood Processing: Principles and Practice, Springer.

WHITTINGTON, P. V. 2013. Risk-Based New Venture Valuation Technique: Win-Win for Entrepreneur and Investor. Journal of Business Valuation and Economic Loss Analysis, 8, 1-26.

\section{Further reading}

For an excellent overview of the use of acoustics in LVL manufacture see: Achim, A.; Paradis, N.; Carter, P.; Hernández, R.E. Using Acoustic Sensors to Improve the Efficiency of the Forest Value Chain in Canada: A Case Study with Laminated Veneer Lumber. Sensors 2011, 11, 5716-5728. Available from http://www.ncbi.nlm.nih.gov/pmc/articles/PMC3231428/.

For facts about the New Zealand Forestry Industry see the Ministry for Primary Industries website at http://www.mpi.govt.nz/forestry/statistics-forecasting/forestry-statistics, in particular their "Facts and Figures" publications.

For a wide range of information on the applications of RFID in Forestry see the publications of the Indisputable Key project: http://interop-vlab.eu/ei public deliverables/indisputablekey.

For a survey of European wood processor's views on Quality control see Quality control of woodproducts in the European timber industry, available from: http://www.ctibtchn.be/useruploads/files/Quality Control Cost E53 2010.PDF.

For an excellent overview of wood property measurement technologies see: Wessels, C. B., F. S. Malan, and T. Rypstra. A review of measurement methods used on standing trees for the prediction of some mechanical properties of timber. European Journal of Forest Research 130.6 (2011): 881-893.

For an excellent overview of timber properties see Jozsa, L. A., and Middleton, G. R. (1994). A discussion of wood quality attributes and their practical implications (pp. 1-42). Vancouver: Forintek Canada Corporation. Also Walker, J. C. F. 2006. Primary Wood Processing: Principles and Practice, Springer. 
Appendix A - Fibre-gen patents

[Redacted]

Table 5: Fibre-gen patents 
Appendix B - Fibre-gen ownership structure

[Redacted]

Figure 7: Fibre-gen ownership structure 
i. Fibre-gen sales model

\begin{tabular}{|c|c|c|c|c|c|c|c|}
\hline Product & Description & $\begin{array}{l}\text { Potential } \\
\text { number of } \\
\text { users }\end{array}$ & $\begin{array}{l}\text { Predicted } \\
\text { take up }\end{array}$ & Cost per unit & Lifetime of unit & $\begin{array}{l}\text { Annual market } \\
\text { size }\end{array}$ & Assumptions \\
\hline $\begin{array}{l}\text { HM200 } \\
\text { (Skid-site } \\
\text { application) }\end{array}$ & $\begin{array}{l}\text { Handheld unit for assessing } \\
\text { felled trees and logs. } \\
\text { VP: Get more } \$ \$ \text { for logs by } \\
\text { matching to highest value } \\
\text { appropriate use. }\end{array}$ & 1000 & $10.00 \%$ & $\$ 12,000.00$ & 5 & $\$ 240,000.00$ & $\begin{array}{l}\text { - Each logging crew (number of logging workers in NZ } \\
\text { / number of loggers per crew) would potentially buy a } \\
\text { single unit, } \\
\text { - That they buy them themselves and are not } \\
\text { provided by the client/forest manager, } \\
\text { - } 10 \% \text { uptake: likely to be at the low end as currently } \\
\text { the value proposition for these groups is poor, } \\
\text { - They replace their units every } 5 \text { years. }\end{array}$ \\
\hline $\begin{array}{l}\text { HM200 } \\
\text { (Mill yard } \\
\text { application) }\end{array}$ & $\begin{array}{l}\text { Handheld unit for assessing } \\
\text { felled trees and logs. } \\
\text { VP: Get more } \$ \$ \text { for logs by } \\
\text { matching to highest value } \\
\text { use. }\end{array}$ & 50 & $30.00 \%$ & $\$ 12,000.00$ & 5 & $\$ 36,000.00$ & $\begin{array}{l}\text { - Each structural mill would potentially buy one unit, } \\
\text { - } 30 \% \text { uptake: likely to be similar as larger mills } \\
\text { currently have a few but are uncommon amongst } \\
\text { smaller mills, } \\
\text { - That it is only relevant to structural mills, } \\
\text { - That is relevant to structural mills of all sizes, } \\
\text { - That verified mills are analogous to the structural } \\
\text { mills, } \\
\text { - They replace their units every } 5 \text { years. }\end{array}$ \\
\hline $\begin{array}{l}\text { HM200 } \\
\text { (Consultancy } \\
\text { application) }\end{array}$ & $\begin{array}{l}\text { VP:Verify average sonic } \\
\text { speeds of shipments from } \\
\text { different sources. Identify } \\
\text { good logs from stands } \\
\text { where all logs are assumed } \\
\text { to be poor and recover } \\
\text { more value. }\end{array}$ & 180 & $30.00 \%$ & $\$ 16,000.00$ & 5 & $\$ 172,800.00$ & $\begin{array}{l}\text { - That there are } 180 \text { forestry consultants who would } \\
\text { each potentially buy a single unit, } \\
\text { - 30\% uptake: likely as tool provides them with a new } \\
\text { revenue stream; most users at the moment are } \\
\text { consultants, } \\
\text { - They replace their units every } 5 \text { years. }\end{array}$ \\
\hline $\begin{array}{l}\text { ST300 (Harvest } \\
\text { planning } \\
\text { application) }\end{array}$ & $\begin{array}{l}\text { Handheld unit for assessing } \\
\text { standing trees. } \\
\text { VP: Increase accuracy of } \\
\text { grade yield predictions. } \\
\text { Increase accuracy of } \\
\text { valuations. }\end{array}$ & 180 & $10.00 \%$ & $\$ 16,000.00$ & 5 & $\$ 57,600.00$ & $\begin{array}{l}\text { - That there are } 180 \text { forestry consultants who would } \\
\text { each potentially buy a single unit, } \\
\text { - } 10 \% \text { uptake: likely to be at the low end as currently } \\
\text { the value proposition for these groups is poor, } \\
\text { - They replace their units every } 5 \text { years. }\end{array}$ \\
\hline
\end{tabular}




\begin{tabular}{|c|c|c|c|c|c|c|c|}
\hline $\begin{array}{l}\text { ST300 (Wood } \\
\text { science } \\
\text { application) }\end{array}$ & $\begin{array}{l}\text { Handheld unit for assessing } \\
\text { standing trees. } \\
\text { VP: Measuring/studying } \\
\text { wood properties. Identify } \\
\text { best trees for breeding. }\end{array}$ & 10 & $60.00 \%$ & $\$ 16,000.00$ & 5 & $\$ 19,200.00$ & $\begin{array}{l}\text { - That Scion would buy } 7 \text { acoustic devices and each of } \\
\text { UC, Massey and Waiaraki teaching institutions would } \\
\text { potentially buy a single unit; } \\
\text { - That } 60 \% \text { of them would use Fibre-gen not } \\
\text { competing products (eg Treetap, Fakopp), } \\
\text { - They replace their units every } 5 \text { years. }\end{array}$ \\
\hline LG640 & $\begin{array}{l}\text { Mill-based unit. } \\
\text { VP: Increase recovery of } \\
\text { high-grade timber. Reduce } \\
\text { costs of processing poor } \\
\text { logs. }\end{array}$ & 50 & $10.00 \%$ & $\$ 150,000.00$ & 10 & $\$ 75,000.00$ & $\begin{array}{l}\text { - Each structural mill would potentially buy one unit, } \\
\text { - } 60 \% \text { uptake: based on impression from } \\
\text { conversations, } \\
\text { - That it is only relevant to structural mills, } \\
\text { - That is is relevant to structural mills of all sizes, } \\
\text { - That verified mills are analogous to the structural } \\
\text { mills, } \\
\text { - That it is not replaced by } \\
\text { Tomography } \backslash \text { interferometer systems, } \\
\text { - That each unit costs } \$ 150,000 \text {, and } \\
\text { - They replace their units every } 10 \text { years. }\end{array}$ \\
\hline PH330 & $\begin{array}{l}\text { Processor head based unit. } \\
\text { VP: Make best log-making } \\
\text { decisions eg if wood is } \\
\text { structural quality cut to } \\
\text { structural length. }\end{array}$ & 40 & $20.00 \%$ & $\$ 88,000.00$ & 10 & $\$ 704,000.00$ & $\begin{array}{l}\text { - That } 50 \% \text { of people who buy a new processor head } \\
\text { will add a PH330, } \\
\text { - They replace their units every } 10 \text { years. }\end{array}$ \\
\hline
\end{tabular}

\begin{tabular}{|l|r|}
\hline $\begin{array}{l}\text { Predicted } \\
\text { annual NZ } \\
\text { market size }\end{array}$ & $\$ 1,304,600.00$ \\
\hline $\begin{array}{l}\text { Total potential } \\
\text { NZ market }\end{array}$ & $\$ 61,220,000.00$ \\
\hline
\end{tabular}

\section{Notes}

- Annual market size taken to be the sum of (potential users * take up * cost per unit) / lifetime of unit, except for the PH330 line as the potential number of users is the number of processor heads sold in NZ per year.

- Potential market size taken to be the sum of (potential users * cost per unit).

- Uptake \%'s inferred from general conversations with industry participants, not specific "would you buy X" questions/surveys.

- Cannibalising effect of tools not specifically quantified. 


\section{ii. PH330 service model}

Market sizing done was done using the following formula as bottom-up sizing was not feasible:

(Sawlog production)*(25\% highest quality timber)*(\$2 per metre cubed finder's fee). These figures are acknowledged to be crude estimates; data for more accurate sizing was not able to be found.

Domestic sawlog production was calculated using NZ Ministry for Primary Industries data to be $1,000,000 \mathrm{~m}^{3}$ per annum.

Global sawlog production was calculated using Eurostat European Commission figures to be approximately $850,000,000 \mathrm{~m}^{3}$ per annum.

Productivity of a processor-head was found from industry interviews to be $180,000 \mathrm{~m}^{3}$ per annum.

This gives a domestic addressable market of $4 \mathrm{~m}$ NZD per annum and a global market of 400m NZD per annum.

This is approximately $25 \%$ of the published global market size for processor-heads which suggest it is reasonable.

\section{iii. WoodCo RFID service model}

Scaled PH330 model by a factor of two - assuming RFID offers a similar amount of value to the rest of industry as stiffness testing. This is borne out by preliminary interviews, especially in light of the fact that this also adds value to low-quality logs.

\section{iv. WoodCo stability measurement service model}

This adds a market of equivalent size to the PH330 as a result of the fact that stability has an equal or larger impact on processors, suggesting its measurement will offer them at least the same amount of value. 


\begin{tabular}{|c|c|c|}
\hline Wood characteristics & Wood/paper properties & $\begin{array}{l}\text { Desired attributes and product } \\
\text { specifications }\end{array}$ \\
\hline $\begin{array}{l}\text { Density, i.e. } \\
\text { cell diameter and wall } \\
\text { thickness }\end{array}$ & $\begin{array}{l}\text { Stiffness } \\
\text { Longitudinal shrinkage } \\
\text { Stability/warp-free }\end{array}$ & $\begin{array}{l}\text { Construction - machine stress } \\
\text { grades: requiring stiffness, } \\
\text { straightness and stability }\end{array}$ \\
\hline $\begin{array}{l}\text { Microfibril angle } \\
\text { Reaction wood } \\
\text { Spiral grain }\end{array}$ & $\begin{array}{l}\text { Machinability/finish } \\
\text { Figure/grain/texture } \\
\text { Hardness }\end{array}$ & $\begin{array}{l}\text { Furniture - quality finish: calling for } \\
\text { hard surfaces; tight joints and little } \\
\text { movement in service; ability to stain }\end{array}$ \\
\hline $\begin{array}{l}\text { Permeability } \\
\text { Heartwood } \\
\text { Extractives }\end{array}$ & $\begin{array}{l}\text { Ease of drying } \\
\text { Colour } \\
\text { Odour }\end{array}$ & $\begin{array}{l}\text { Newsprint - high speed printing, } \\
\text { resilience, adequate brightness, } \\
\text { opacity, low-cost }\end{array}$ \\
\hline $\begin{array}{l}\text { Tracheid length } \\
\text { Coarseness } \\
\text { More cellulose } \\
\text { Less lignin }\end{array}$ & $\begin{array}{l}\text { Tear strength } \\
\text { Brightness (less } \\
\text { bleaching) }\end{array}$ & $\begin{array}{l}\text { Paperboard and packaging - } \\
\text { requiring good handling and } \\
\text { serviceability (burst, wet-strength), } \\
\text { clear print }\end{array}$ \\
\hline
\end{tabular}

Figure 8: Key wood micro and macro properties (Walker, 2006) 
Appendix E - WoodCo technology sources

\begin{tabular}{lll}
\hline Component & $\begin{array}{l}\text { Potential } \\
\text { source }\end{array}$ & Notes \\
\hline RFID Tags & Confidex. & $\begin{array}{l}\text { Confidex developed an RFID tag especially for use in the } \\
\text { forest supply-chain, as part of the Swedish "Indisputable } \\
\text { Key" (IK) project in 2010. It does not appear to have } \\
\text { been commercialised. A cursory patent search found no } \\
\text { relevant issued patents. }\end{array}$ \\
\hline Tag applicator & $\begin{array}{l}\text { Develop in- } \\
\text { house. }\end{array}$ & $\begin{array}{l}\text { The IK project included the development of a } \\
\text { mechanised tag applicator. This is understood to be a } \\
\text { simple mechanical design that could be easily replicated } \\
\text { (especially with the available information from the IK } \\
\text { project). }\end{array}$ \\
\hline $\begin{array}{l}\text { Management } \\
\text { software }\end{array}$ & $\begin{array}{l}\text { Develop in- } \\
\text { house. }\end{array}$ & $\begin{array}{l}\text { This could either be developed in house, or the data } \\
\text { could be exposed via API to third party developers and } \\
\text { logistics systems. }\end{array}$ \\
\hline $\begin{array}{l}\text { Measurement } \\
\text { platform }\end{array}$ & Fibre-gen. & $\begin{array}{l}\text { This refers to the platform elements of the Fibre-gen } \\
\text { design; the hard and soft integrations with existing } \\
\text { processor-heads and the development of robust sensors. }\end{array}$ \\
\hline $\begin{array}{l}\text { Stiffness } \\
\text { measures }\end{array}$ & Fibre-gen. & $\begin{array}{l}\text { This refers to Fibre-gen's acoustic stiffness-measurement } \\
\text { technology. }\end{array}$ \\
\hline $\begin{array}{l}\text { Stability } \\
\text { measures }\end{array}$ & TBD. & $\begin{array}{l}\text { There are a number of micro-attributes which lead to } \\
\text { the bulk property of stability. The exact impact of each of } \\
\text { these, and how each can be measured in the field, } \\
\text { remains to be seen. }\end{array}$ \\
\hline $\begin{array}{l}\text { Physical } \\
\text { measures }\end{array}$ & $\begin{array}{l}\text { Fmbedded } \\
\text { processor- } \\
\text { head sensors. }\end{array}$ & $\begin{array}{l}\text { is some debate over their accuracy, and they may not } \\
\text { measure characteristics such as sweep, wobble .etc }\end{array}$ \\
\hline
\end{tabular}


Appendix F - Useful contacts

[Redacted] 


\section{Appendix G - Exit strategy}

i. Large players

\section{John Deere}

- No history of acquisitions found in forestry since Timberjack in 2000.

- Evidence in wider group of purchasing IP rights to incorporate into their crop harvesters.

- Tend to pursue joint ventures instead of acquire.

\section{Weiyerhaueser}

- Have patents and R\&D in the exact area, and are massive, but no history of acquiring small technology companies.

\section{Trimble}

- Have a forestry division focused on optimization and productivity of supply-chain.

- Acquired Asset Forestry Ltd (Asset) in September 2013 for an undisclosed amount. Asset are a forestry logistics business who provide timber dispatch and inventory management IT systems.

- Have also acquired 2 other NZ tech companies - Actronic Technologies Ltd and IQ Irrigation Ltd.

\section{Komatsu}

- Acquired processor-head manufacturer LogMax in 2012 for NZ\$79.4m.

Integral Ltd

- Bought ATLAS in October 2013 from Scion. Atlas provide forestry management/modelling software.

\section{ii. Analogous deal: El-Forest AB}

- El-Forest are a Swedish company developing hybrid forwarders (machines for transporting logs in-forest) which are more efficient and utilise patented wheeltrack technology to reduce damage to the forest floor and soil.

- Founded in 2006.

- $38 \%$ of shares acquired by Volvo Technology Transfer. Valuation/price unknown.

- Forwarder trial unit completed in 2009.

- Had revenues of 3m SEK (NZ\$652K) in 2009.

- Awarded patent for an "electrically propulsed vehicle" in 2010. filed applications for 2 more.

- Entered production pilot in 2010.

- In 2010 Swedish state-owned VC FourierTransform invested 20m SEK ( NZ\$3.5m) in exchange for $36 \%$ shareholding at a pre-money valuation of NZ\$ $6.2 \mathrm{~m}$. They had 7 employees.

- As of 2012, FourierTransform carried $48 \%$ of El-Forest shares at 27.9m SEK $(\sim N Z \$ 5.2 \mathrm{~m})$, giving a fair value of $\sim \mathrm{NZ} \$ 10.8 \mathrm{~m}$. 
- In 2012 revealed a joint-venture with ProSilva for the world's first electric hybrid harvester.

- In 2013 FourierTransform invested a further 2.5m SEK via a convertible loan. 
Appendix $\mathrm{H}$ - Full forestry production chain

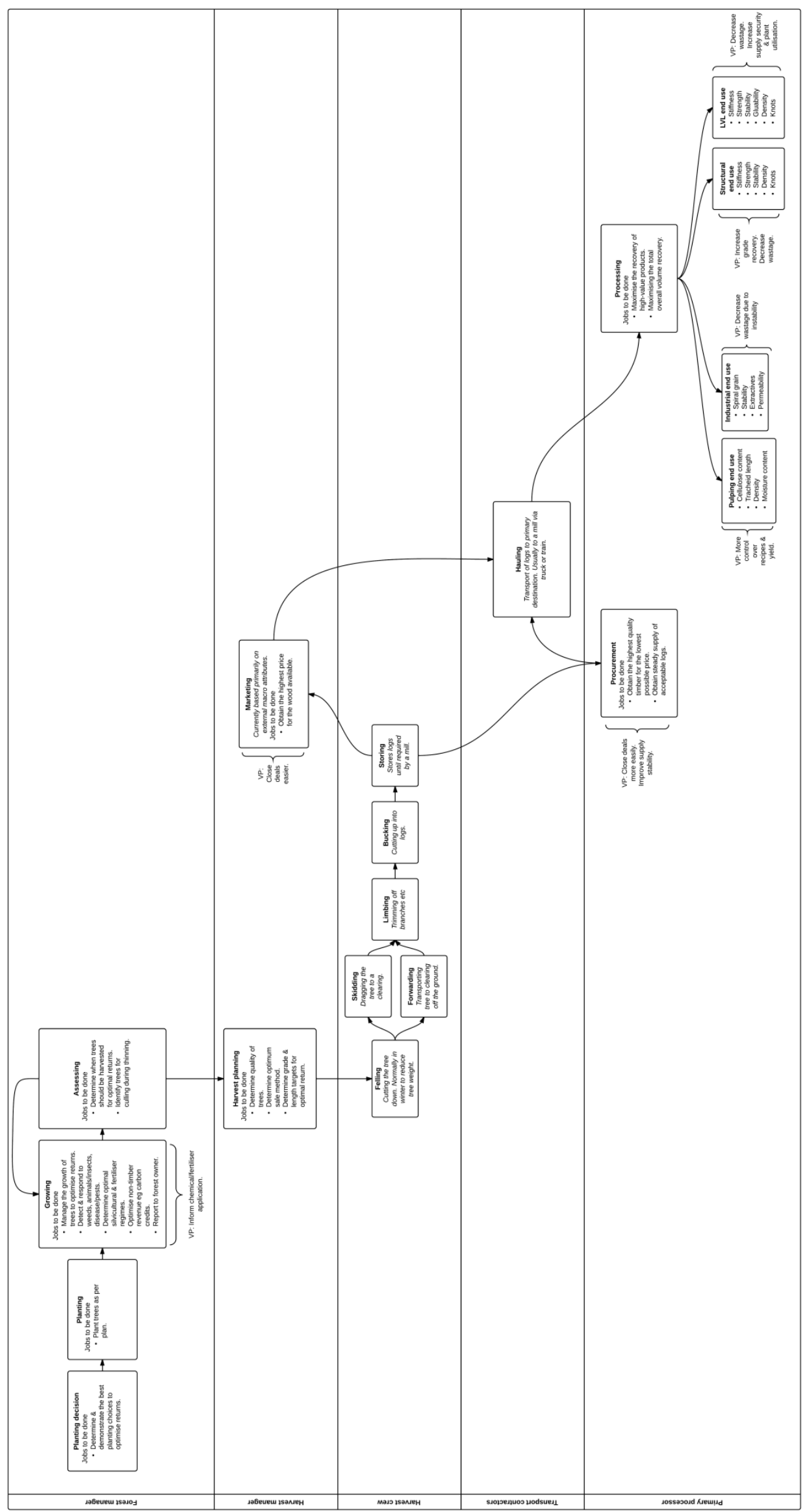




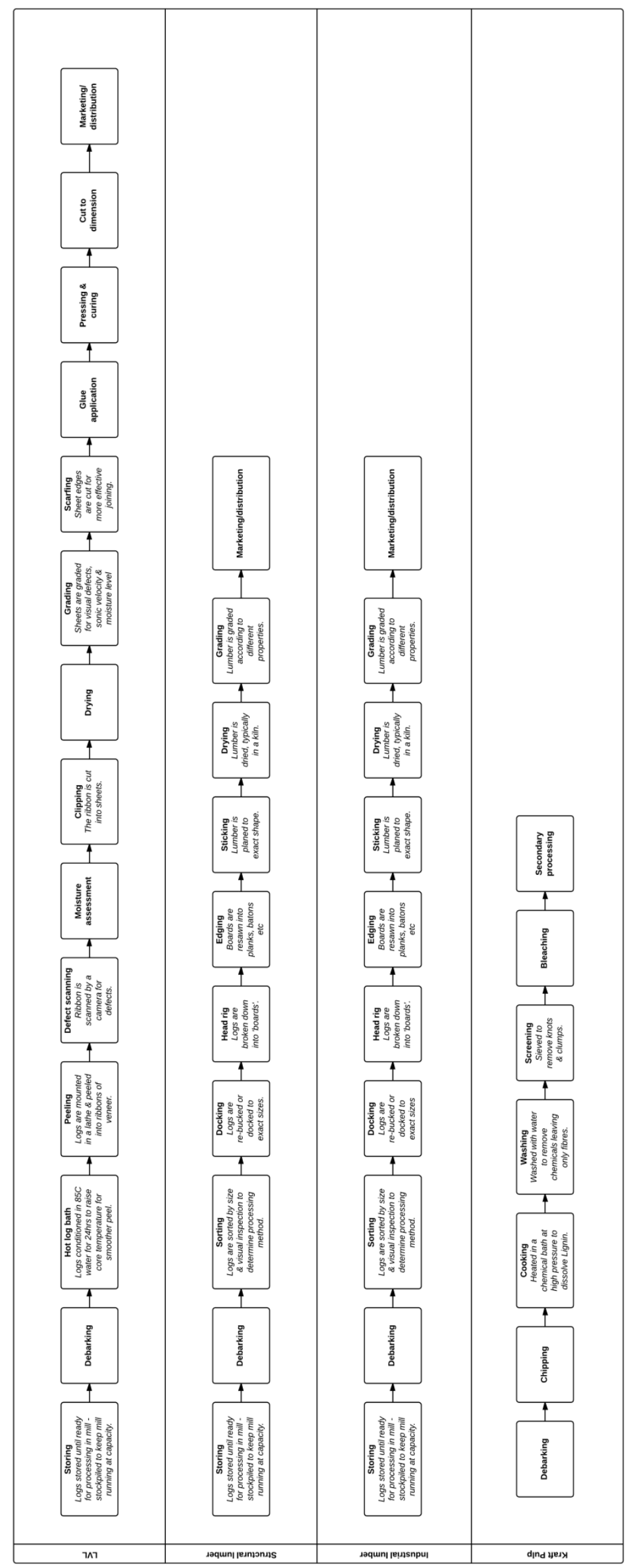




\section{Appendix I - Industry interviews}

Throughout this project a number of unstructured interviews were held with various members of the Forestry industry. The following is a record of these.

\begin{tabular}{|c|c|c|c|c|c|}
\hline Company & Name & Details & Phone number & Date called & Notes \\
\hline [redacted] & [redacted] & $\begin{array}{l}\text { Forest/ } \\
\text { harvest } \\
\text { managers }\end{array}$ & [redacted] & $31 / 10 / 2013$ & $\begin{array}{l}\text { - Specifications of logs can be whatever demanded by customer; each can } \\
\text { have different metric requirements. } \\
\text { - Forest owners would love to get value for what is actually grown. } \\
\text { - There is no measurement of internal qualities required for export. } \\
\text { - Density is measured by those "scanny things". } \\
\text { - Generally what is measured/specified is that which is easy to measure as } \\
\text { opposed to that which is useful. } \\
\text { - Forest owners often don't see a financial benefit from investing in } \\
\text { genetically enhanced seedlings (or maybe can't quantify/predict it when } \\
\text { making the purchasing decision). } \\
\text { - Feel too much goes to fibre. }\end{array}$ \\
\hline [redacted] & [redacted] & $\begin{array}{l}\text { Log/lumber } \\
\text { merchants }\end{array}$ & [redacted] & $30 / 10 / 2013$ & $\begin{array}{l}\text { - Chinese are happy with log consistancy which arises from visual } \\
\text { segregation } \\
\text { - One log supplier acoustically screens and only exports logs that aren't } \\
\text { structural grade; Chinese buyers have noticed this. } \\
\text { - Echoed that end use of export logs is not for structural purposes, largely } \\
\text { plywood for shuttering. } \\
\text { - Export markets not asking for any more information. } \\
\text { - Could be used to differentiate NZ timber if a comprehensive } \\
\text { education/marketing plan was conducted. }\end{array}$ \\
\hline [redacted] & [redacted] & $\begin{array}{l}\text { Forest/harves } \\
\text { t managers }\end{array}$ & [redacted] & $1 / 11 / 2013$ & $\begin{array}{l}\text { Really good to talk to - happy to talk again. NB [redacted] has actually been } \\
\text { involved with [redacted] in the past (found out later). } \\
\text { General } \\
\text { - Three sectors within forestry - growing, processing, researching. } \\
\text { - Only } 15 \% \text { of NZ logs destined for structural use. } \\
\text { - Very few mills now own their own forests. } \\
\text { - Three most important log qualities are currently length, diameter and } \\
\text { branching habit (branches/knots). }\end{array}$ \\
\hline
\end{tabular}




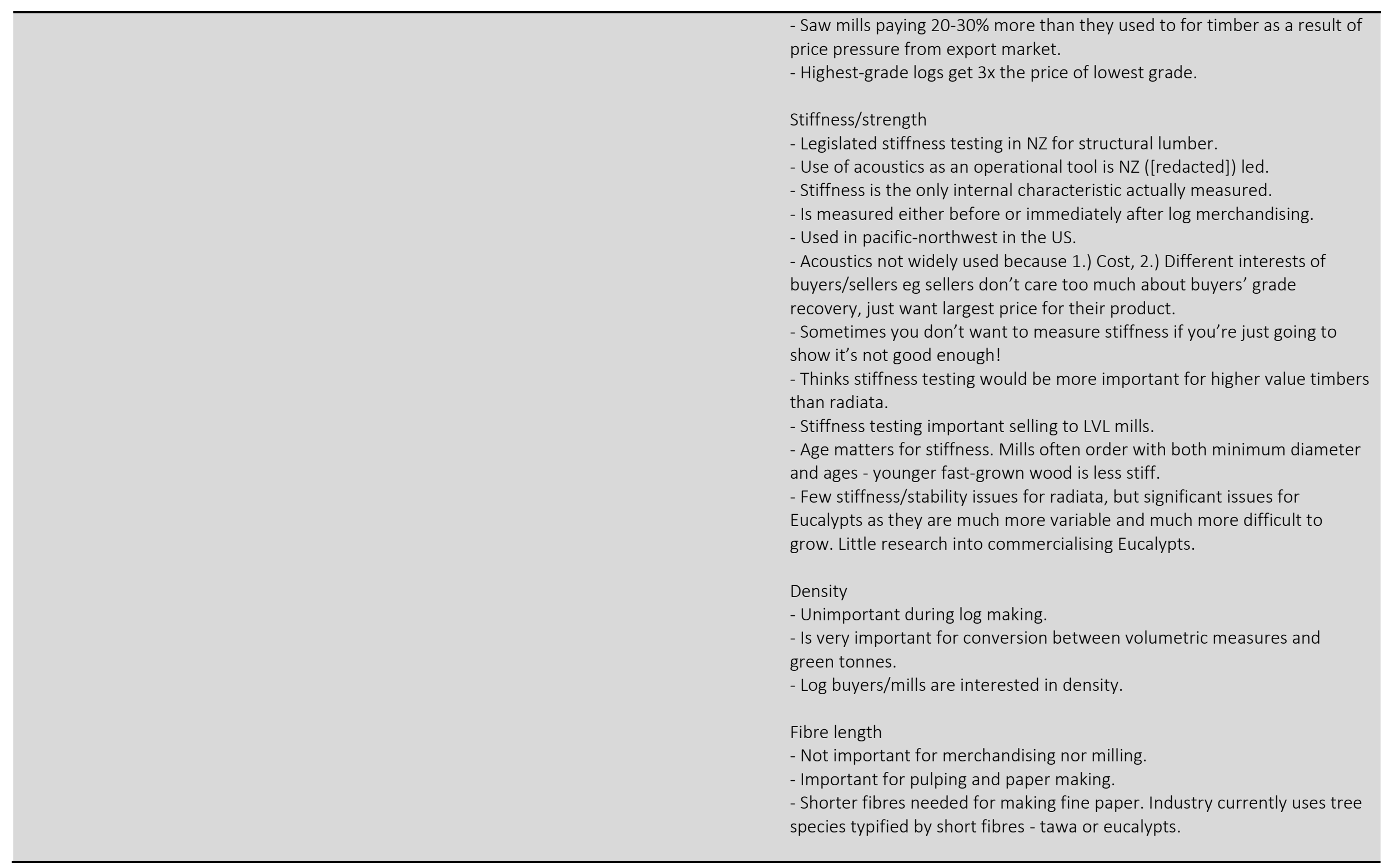




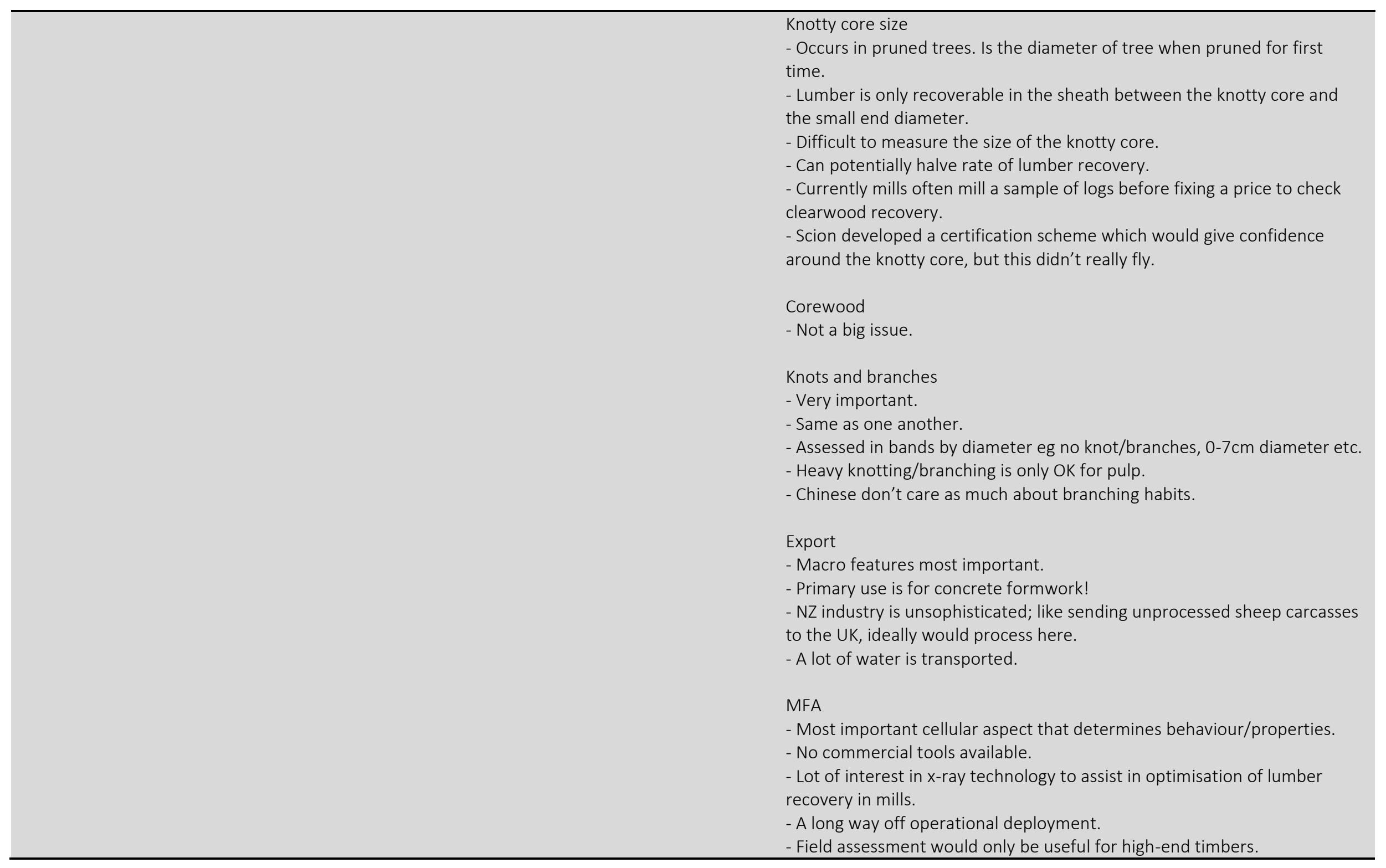




\begin{tabular}{|c|c|c|c|c|c|}
\hline & & & & & - Could be used to differentiate NZ Radiata as a high-end product. \\
\hline [redacted] & [redacted] & $\begin{array}{l}\text { Forest/harves } \\
\text { t managers }\end{array}$ & [redacted] & $30 / 10 / 2013$ & $\begin{array}{l}\text { - Measure stand PLI and density } \\
\text { - Focus is on volume recovery }\end{array}$ \\
\hline [redacted] & [redacted] & $\begin{array}{l}\text { Wood } \\
\text { scientist }\end{array}$ & [redacted] & $1 / 11 / 2013$ & Referred by [Redacted]. Emailed to organise a time to call. \\
\hline [redacted] & [redacted] & Mill & [redacted] & $1 / 11 / 2013$ & $\begin{array}{l}\text { General } \\
\text { - Chinese effect on log prices and wood-flows is the single largest } \\
\text { challenge for sawmillers. } \\
\text { - Sonics heavily used in North Zealand. } \\
\text { - Try to only buy sonic rated logs, and use the sonic mill unit and find it } \\
\text { really good. } \\
\text { - China determines log prices. } \\
\text { Logs } \\
\text { - Look for a structural log sonic rating. } \\
\text { - Max knot diameter. } \\
\text { - Min } 30 \mathrm{~cm} \text { SED. } \\
\text { - Find log sonic rating means grade outturns can be accurately predicted. }\end{array}$ \\
\hline [redacted] & [redacted] & $\begin{array}{l}\text { Forest/harves } \\
\text { t managers }\end{array}$ & [redacted] & $5 / 11 / 2013$ & $\begin{array}{l}\text { - Visual log grading is the norm. } \\
\text { - Everything is market-driven; if the mills etc require sonic testing or } \\
\text { incentivise it then it will be done. } \\
\text { - No price premium for sonic tested logs. } \\
\text { - Age of trees is important. }\end{array}$ \\
\hline [redacted] & [redacted] & Mill & [redacted] & $5 / 11 / 2013$ & $\begin{array}{l}\text { - Segregate pruned and K-grade logs out. } \\
\text { - Get consistant returns from log grades as-is. } \\
\text { - Not making structural lumber. }\end{array}$ \\
\hline [redacted] & [redacted] & MII & [redacted] & $5 / 11 / 2013$ & $\begin{array}{l}\text { - Optical scanners are used to detect knots etc. } \\
\text { - They don't produce structural lumber so don't care too much. } \\
\text { - Optical scanners made a big difference. } \\
\text { - Happy to talk again. }\end{array}$ \\
\hline [redacted] & [redacted] & $\begin{array}{l}\text { Forest/harves } \\
\text { t managers }\end{array}$ & [redacted] & $6 / 11 / 2013$ & $\begin{array}{l}\text { - Cost of implementation is a big issue for uptake of stiffness tools. } \\
\text { - Timbertech is used in industry for scanning logs. } \\
\text { - Sonic testing largely done for samples. } \\
\text { - Wider adoption of sonics wood be good for industry. }\end{array}$ \\
\hline
\end{tabular}




\begin{tabular}{|c|c|c|c|c|c|}
\hline & & & & & $\begin{array}{l}\text { - Low quality timber is sometimes left on the ground if haulage costs are } \\
\text { too high. }\end{array}$ \\
\hline [redacted] & [redacted] & Mill & [redacted] & $6 / 11 / 2013$ & $\begin{array}{l}\text { - If done, Sonic testing is mainly done on site. } \\
\text { - Main issue is cost. } \\
\text { - Main issue for mills is log supply/price - forest managers only care about } \\
\text { \$\$ return. } \\
\text { - Fibre recovery = Volume recovery. } \\
\text { - Speed of processing is important. } \\
\text { - } 4 \text { Important things for mills: } \\
\text {-- Fibre recovery } \\
\text {-- Grade outturn } \\
\text {-- Cutting to order - matching sales requirements to resources. } \\
\text {-- Reducing costs - going faster and improving accuracy. } \\
\text { - For most mills a sawlog is a sawlog, they trust it will give them the grade } \\
\text { recovery they need. They do monitor and trace back if it doesn't however. } \\
\text { - Would like an email about wood quality findings: [redacted] }\end{array}$ \\
\hline [redacted] & [redacted] & Mill & [redacted] & $6 / 11 / 2013$ & $\begin{array}{l}\text { - Visual grading is the norm. } \\
\text { - Use [redacted]'s tools to assess quality of suppliers. } \\
\text { - Need to show that acoustic tools are worth-while, quantify the benefits } \\
\text { to processors eg: "x\% stiffness increase corresponds to \$yyy extra revenue } \\
\text { or zzz m3 extra recovery". } \\
\text { - Stiffness can be a big problem, moreso down south. } \\
\text { - Two important measures are core density and sonics. Density is } \\
\text { commonly supplied. } \\
\text { - Would be good to have tech to make on the fly value optimisation } \\
\text { decisions for making log grades. } \\
\text { - Was involved with [redacted] trial } 4 \text { years ago, worked and thought was } \\
\text { headed in right direction but not robust enough. } \\
\text { - Most decisions are currently made on stand average values. } \\
\text { - Large variation in forests but hard to cost-effectively segregate. } \\
\text { - What to do with timber that is not up to scratch? Once you've taken the } \\
\text { good stuff who will buy the bad stuff? }\end{array}$ \\
\hline [redacted] & [redacted] & Mill & [redacted] & $6 / 11 / 2013$ & $\begin{array}{l}\text { - Use acoustic segregation in the yard to determine the cut patterns. } \\
\text { - Big mills are sonic testing, is too expensive for smaller mills. } \\
\text { - Difficult for mills to justify investment in expensive tech when log supply }\end{array}$ \\
\hline
\end{tabular}




\begin{tabular}{|c|c|c|c|c|c|}
\hline & & & & & $\begin{array}{l}\text { is uncertain. } \\
\text { - Appearance grade is lower value than structural. } \\
\text { - Believes they are one of the few mills who sonically test logs. } \\
\text { - Does give them higher levels of grade recovery. } \\
\text { - MiCROTEC too expensive. } \\
\text { - Think chord and defect scanning is important, avoiding pith (middle } 10 \\
\text { growth rings). } \\
\text { - Sonics shift focus from fibre recovery to grade recovery. } \\
\text { - Increasing grade recovery by 1-2\% justifies a volume reduction of 1-2\%. } \\
\text { - Seems there would be an opportunity for cheaper Sonic Testing/different } \\
\text { business model? }\end{array}$ \\
\hline [redacted] & [redacted] & Mill & [redacted] & $6 / 11 / 2013$ & $\begin{array}{l}\text { - Have a [redacted] tool but don't use it: call [redacted]. } \\
\text { - Want higher density logs primarily. } \\
\text { - [redacted] can tell some things but doesn't supply a complete picture. } \\
\text { - Would be most useful if stiffness testing happened on unloading of logs } \\
\text { as it is often too late to reject logs after that point. } \\
\text { - Primarily rely on experience. } \\
\text { - Cutting logs to order is important. } \\
\text { - A big issue is stone detection in logs as this can bugger mill equipment. } \\
\text { - Average stiffness of a log is maybe not that useful. }\end{array}$ \\
\hline
\end{tabular}




\begin{tabular}{|c|c|c|c|c|c|}
\hline & & & & & - Happy to talk again. \\
\hline [redacted] & [redacted] & Mill & [redacted] & $7 / 11 / 2013$ & $\begin{array}{l}\text { - Use some [redacted] tools in the yard. } \\
\text { - Density testing is important. } \\
\text { - Density measured by weighing log. } \\
\text { - Interpine do random sampling of wood supplies using [redacted] tools. } \\
\text { - Segregate log supply in yard into logs that will yield SG8 and fibre/export } \\
\text { material logs. } \\
\text { - No real issues with stones and sand after debarking and washing. } \\
\text { - Wants scanners to replace visual graders as these are the main sources } \\
\text { of output quality problems. }\end{array}$ \\
\hline [redacted] & [redacted] & $\begin{array}{l}\text { Forestry } \\
\text { operations }\end{array}$ & [redacted] & $11 / 11 / 2013$ & $\begin{array}{l}\text { - Need to demonstrate internal characteristics becoming more important } \\
\text { with fast growing plantations. } \\
\text { - Fibre strength, fibre/lignin contents are important to pulp-makers. } \\
\text { - [redacted] may be a joint development with a Scottish company. } \\
\text { - Key limitation of uptake of acoustics are contracts: don't require/pay a } \\
\text { premium for wood shown to be stiffer. Would be good for industry and } \\
\text { industry is moving that way. } \\
\text { - Needs to be easily integrated to existing log-making systems. } \\
\text { - About } 40 \% \text { of Australian timber doesn't make structural grade. } \\
\text { - Stiffness is most important property. } \\
\text { - Pulp yield prediction is really important - a } 1 \% \text { increase in pulp yield can } \\
\text { be worth } \$ 1,000,000 \text { for large pulp mills. } \\
\text { - Again contracts aren't structured to recognise better internal } \\
\text { characteristics - may enforce a minimum requirement though. } \\
\text { - Gluability is important for engineered wood products. } \\
\text { - Knotty core only relevant to pruned logs. } \\
\text { - Forest owners normally have multiple customers they can send different } \\
\text { products (eg log qualities) to. } \\
\text { - Segregation currently occurs based on external characteristics. }\end{array}$ \\
\hline [redacted] & [redacted] & Mill & [redacted] & $8 / 11 / 2013$ & $\begin{array}{l}\text { - Inspect loads of logs when they arrive to ensure they are in spec. } \\
\text { - Every month trace clearwood recovery back to suppliers. } \\
\text { - Ranks every source via PLI (Pruned Log Index), resin analysis and for } \\
\text { inter-ring checking. } \\
\text { - Run mill trials to determine wood quality. } \\
\text { - Fletcher developed their own tool that they're contractually OK to use. }\end{array}$ \\
\hline
\end{tabular}




\begin{tabular}{|c|c|c|c|c|c|}
\hline & & & & & $\begin{array}{l}\text { - Take a wood density score with each load. } \\
\text { - Just want to stop particularly bad supply. } \\
\text { - Knotty/defect core is important. } \\
\text { - Online, real-time quality management would be good. } \\
\text { - Sonics essential within structural mills. } \\
\text { - No faith at all in stading tree tool. } \\
\text { - Only uses sonics when required by customer. }\end{array}$ \\
\hline [redacted] & [redacted] & Log purchaser & [redacted] & $13 / 11 / 2013$ & $\begin{array}{l}\text { - Not really the right person to talk to. } \\
\text { - Said defect core was a big issue for pruned logs as no idea of pruning } \\
\text { quality beforehand. }\end{array}$ \\
\hline [redacted] & [redacted] & Pulp mill & [redacted] & $13 / 11 / 2013$ & $\begin{array}{l}\text { - Density most important. } \\
\text { - Uses a knowledge of what comes from where to predict likely quality. } \\
\text { - Control fibre-length by altering proportion of saw-mill chips in each } \\
\text { batch. } \\
\text { - With logs you more or less "get what you get". } \\
\text { - Believes density is a good proxy for fibre-length. } \\
\text { - Would find more information useful but wouldn't pay more for it; feels } \\
\text { he basically has enough information. } \\
\text { - Would want to measure fibre-length better if saw-mills close reducing } \\
\text { the available supply of chip. } \\
\text { - Many variables define pulp yield, more info would be useful. } \\
\text { - Would be useful if mechanised harvesting equipment could capture } \\
\text { more data, store in a DB, then link to individual logs via RFID. } \\
\text { - "When Asian markets are happy to take anything then it impacts the } \\
\text { behaviour of suppliers". } \\
\text { - Stop selling as weight and start selling as volume. }\end{array}$ \\
\hline [redacted] & [redacted] & Pulp mill & [redacted] & $13 / 11 / 2013$ & Call back. Emailed questions through. \\
\hline [redacted] & [redacted] & Pulp mill & [redacted] & $13 / 11 / 2013$ & $\begin{array}{l}\text { - Pretty happy with wood supply - they get it from the same } \\
\text { people/regions so know more or less what they're getting. } \\
\text { - } 75 \% \text { of their fibre supply is from sawmill chips from structural mills - they } \\
\text { know that this chip will likely have long fibre length and high density. } \\
\text { - They track wood quality. }\end{array}$ \\
\hline [redacted] & [redacted] & $\begin{array}{l}\text { Harvest } \\
\text { manager }\end{array}$ & [redacted] & $13 / 11 / 2013$ & $\begin{array}{l}\text { - Processing yard is where fulls stems are taken to be bucked up. } \\
\text { - Density measured during pre-harvest inventory. } \\
\text { - Bucking decisions based on structural supply and demand. }\end{array}$ \\
\hline
\end{tabular}




\begin{tabular}{|c|c|c|c|c|c|}
\hline & & & & & $\begin{array}{l}\text { - Density is the only wood supply requirement for Carter Holt Harvey. } \\
\text { - Don't use [redacted] much. } \\
\text { - Some wood supply agreements require the use of sonics. } \\
\text { - Thinks sonics are the equivalent of measuring density. } \\
\text { - Thinks RFID presents a big opportunity, especially for export market. } \\
\text { - Room for improvement in density testing. }\end{array}$ \\
\hline [redacted] & [redacted] & Mill & [redacted] & $13 / 11 / 2013$ & $\begin{array}{l}\text { - Most important parameters are length, SED, knot size. } \\
\text { - Thinks [redacted] measures density, but they feel they can predict the } \\
\text { density with ok accuracy based on historical deliveries. } \\
\text { - Use Metriguard acoustic grader post-processing. } \\
\text { - } 4 \% \text { of logs in a shipment can be out of Spec. } \\
\text { - More knowledge sharing would be good. } \\
\text { - They're the only real veneer sales company. }\end{array}$ \\
\hline [redacted] & [redacted] & $\begin{array}{l}\text { Forest/harves } \\
\text { t managers }\end{array}$ & [redacted] & $13 / 11 / 2013$ & $\begin{array}{l}\text { - Nett stumpage returns heavily impacted by location. } \\
\text { - Mills have issues if wood is too young. } \\
\text { - Use [redacted] sometimes. } \\
\text { - [redacted] used for logs going into NPI, McAlpine. }\end{array}$ \\
\hline [redacted] & [redacted] & $\begin{array}{l}\text { Forest/harves } \\
\text { t managers }\end{array}$ & [redacted] & $13 / 11 / 2013$ & $\begin{array}{l}\text { - Happy to talk again } \\
\text { - Mainly external physical characteristics measured at harvest } \\
\text { - Log suppliers sometimes do QC by sampling random truckloads for } \\
\text { compliance with specification; about } 2 \% \text { of total supply. } \\
\text { - Log purchasers may also do QC in a similar way } \\
\text { - Logs are chosen based on average values resulting from a knowledge of } \\
\text { regions and forests } \\
\text { - Sonic tools give an accurate measure of wood strength. Used to give an } \\
\text { exact cut-off acoustic velocity for structural logs. } \\
\text { - Marginal forests are the main users of tools to segregate logs on the skid } \\
\text { site } \\
\text { - Kaingaroa processing facility takes full stems and optimally bucks them } \\
\text { and sounds like [redacted] is used. } \\
\text { - No price premium for supplying sonic measurements, a structural log is a } \\
\text { structural log. }\end{array}$ \\
\hline [redacted] & [redacted] & $\begin{array}{l}\text { Processor } \\
\text { head sales }\end{array}$ & [redacted] & $6 / 12 / 2013$ & $\begin{array}{l}\text { - } 35 \% \text { of NZ felling uses processor heads } \\
\text { - } 300 \text { Waratah heads in operation in NZ } \\
\text { - Heads owned by contractors, generally between } 1 \text { head and } 5\end{array}$ \\
\hline
\end{tabular}




\begin{tabular}{|c|c|c|c|c|c|}
\hline & & & & & $\begin{array}{l}\text { - Range from } \$ 200 k \text { to } \$ 300 k \text { installed } \\
\text { - Use of heads with cut to length optimisation mandated by big forests } \\
\text { - Main selling point to contractors is both increased safety and also that it } \\
\text { is a visible safety measure } \\
\text { - Advantage of useto contractor is increased throughput } \\
\text { - Advantage to forest owner of having real data - not "guesstimated" } \\
\text { - Problem with [redacted]: WHO WILL PAY. } \\
\text { - Application of RFID is in its infancy and predicted to be huge } \\
\text { - Bucking optimisation is effective } \\
\text { - Waratah moving towards integrated sensors to include internal qualities } \\
\text { in bucking models } \\
\text { - Multiple log piles on skid sites are not a big issue }\end{array}$ \\
\hline [redacted] & [redacted] & $\begin{array}{l}\text { Log } \\
\text { production } \\
\text { manager }\end{array}$ & [redacted] & $28 / 1 / 2013$ & $\begin{array}{l}\text { - Information sharing alone wood be valuable to wood producers; it avoids } \\
\text { them having to be constantly repeating measurements. } \\
\text { - Conventional log tagging is quite expensive due to the repeat } \\
\text { measurements. } \\
\text { - Logs are cut dependent on the orders the company has. } \\
\text { - Buying and selling of logs is done differently by all different companies in } \\
\text { NZ. } \\
\text { - Over } 100 \text { log grades cut in NZ. } \\
\text { - Uses [redacted] to hit a few logs, don't need to do most as they're from a } \\
\text { good region. } \\
\text { - Biggest structural mills are in Kawerau. } \\
\text { - FSC certification is pretty labour intensive. } \\
\text { - Pruned mills care about clearwood (cf knotty core). } \\
\text { - Processor-head measurements are limited and not particularly accurate. } \\
\text { The operator merely looks for knots, sweep etc on the logs and grades it } \\
\text { as } 1-4 \text {. These aren't currently measured by the processor head. } \\
\text { - Definitely a massive push to more automation. } \\
\text { - Transport costs are difficult to manage effectively. } \\
\text { - Increases in logging and transport costs over the value of wood is driving } \\
\text { innovation in the sector. } \\
\text { - Overall, just sharing information across the chain would be most } \\
\text { valuable. }\end{array}$ \\
\hline
\end{tabular}

